\title{
ON THE CHANGES
}

OBSERVED IN

\section{HEALTHY MEDIUM-SIZED ARTERIES AND IN TENDON LIGATURES}

DURING THE FIRST FOUR WEEKS

\section{AFTER LIGATION.}

BY

SHERIDAN DELEPINE, M.B., B.Sc., lecturer on pathology, st. george's hospital;

AND

C. T. DENT, F.R.C.S.,

- ENIOR ASSISTANT SURGEON, ST. GEORGE's HOSPITAL.

Received January 13th-Read May 26th, 1891.

GENERAL SUMMARY.

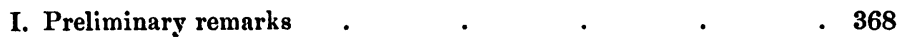

II. Experiments :

1. Nature . $\quad . \quad$. $\quad . \quad$. 369

2. Methods . $\quad • \quad$ - $\quad$ - $\quad$ - $\quad 370$

1II. Macroscopical appearances of the arteries :

1. Contents

2. Walls -.

3. Perivascular tissue $\quad$. $\quad$. $\quad$. $\quad 376$

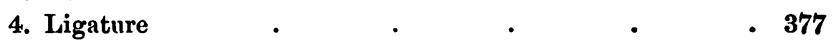


IV. Microscopical appearances of the arteries :

$\begin{array}{lllllll}5 \text { th day after ligature } & . & . & & & & \end{array}$

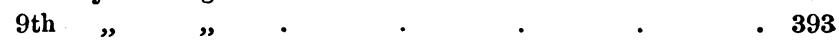

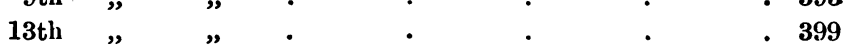

17 th $"$ " . $\quad . \quad$. 402

20th $"$ " .

23rd " $"$.

V. Summing up and interpretation of the changes observed $\quad .409$

VI. Criticism of views held by other observers :

1. Anatomico-physiological $\quad$. $\quad$. $\quad$. $\quad 415$

A. Coagulation $\quad . \quad$. $\quad . \quad 417$

$\begin{array}{lllll}\text { B. Organisation } & \text {. } & \text {. } & \text {. } & \text {. } 419\end{array}$

c. Vascularisation $\quad . \quad$. $4 \quad$. $4 \quad .420$

D. Fate of ligature $\quad$. $\quad$. $\quad$. $\quad$. 424

2. Clinical .

E. Periarterial changes . $\quad$. $\quad$. $\quad$. 424

VII. General conclusions .

\section{Preliminary Remarks.}

Ten years ago, one of us brought before the Society a paper $^{1}$ in which the behaviour of a tendon ligature was dealt with. In the course of the discussion that followed, a promise was made that the results of further observations on the same subject should also be communicated, in due course, to the Society. The long delay in the fulfilment of this promise has been due to various causes. As a matter of fact, indeed, all the results of the investigation which we now bring forward were already obtained early in 1886. The reading of Messrs. Ballance and Edmunds's paper $^{2}$ before the Society was one reason that deterred us from launching our paper during the same session. With the exception of a few notes published by one of us concerning the organisation of the clot, ${ }^{3}$ we allowed the matter to drop for the time, being of opinion that the subject had perhaps been sufficiently under discussion,

1 Dent, 'Med.-Chir. Trans.,' vol. lxiv, 1881, p. 231.

2 'Med.-Chir. Trans.,' vol. lxix, 1886, p. 443.

3 Delépine, ‘ Brit. Med. Journal,’ 1887. 
and fearing that it might prove wearisome. We are, however, so convinced that some of our facts have a distinct bearing upon the practice of ligation of arteries in their continuity, that it does not seem right to withhold them any longer.

Since the immediate changes occurring after ligation have been studied and described by numerous observers, e.g. Stilling, Billroth, Cornil, Ranvier, and Shakespeare, as well as by many other old and recent writers, it was not thought necessary to re-investigate this branch of the subject. Moreover the main object of the investigation was not the study of the causes of thrombosis.

Our inquiry was directed chiefly to ascertaining the effects of a certain form of ligature applied tightly to the vessel. Earlier than the fifth day after ligation, little of practical utility could be added to the knowledge already gained. Further, if the method was a good one, all the changes necessary to produce complete and permanent obstruction were expected to be completed within three weeks. These considerations will explain the limits of time within which our observations extend.

\section{Experiments.}

Nature of the Experiments.

The femoral arteries of six sheep were tied with chromo-carbolised kangaroo tendon by Professor E. C. Stirling, in Australia, on September 7th, 1884.

The 1st sheep was killed 5 days after the operation.

\begin{tabular}{|c|c|c|c|}
\hline 2nd & & 9 & \\
\hline $3 \mathrm{rd}$ & 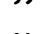 & 13 & נו \\
\hline 4th & 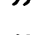 & 17 & $"$ \\
\hline 5 th & " & 0 & " \\
\hline 6 th & 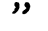 & 00 & 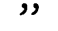 \\
\hline
\end{tabular}

In every case the ligature was tightly tied, so as to cause rupture of the internal coats. The operation, pervol. LXXIV. 
formed with antiseptic precautions, was successful in all cases; all the wounds healed without suppuration. After removal from the body the ligatured portion of the arteries with part of the surrounding tissues was placed in $\frac{1}{6}$ per cent. chromic acid mixture, then in methylated spirit in the usual way, and after this the specimens were sent to England. ${ }^{1}$

\section{Preparation of the Specimens examined.}

In order to display the relations of their parts, all the specimens were carefully bisected in such a way as to include in the plan of section the constricted part of the artery, the knot of the ligature, and the traumatic region (that is the line of the incision made for the purpose of exposing the ressel). It may be remarked here that this section was tolerably easy to carry out in the specimens obtained soon after the operation. In the last three, however, the difficulty was very great, owing to the deformity caused by contraction or other causes, which had produced more or less marked tortuosity of the vessel. One half of the artery was kept for the purpose of cutting longitudinal sections for microscopical examination. The other half was used for the purpose of cutting transverse sections at various levels.

It was found afterwards that by far the most useful sections were the longitudinal ones, especially those passing through the whole course of the constricted portion of the artery, showing the knot of the ligature on one side. In addition to these two modes of preparation, small portions of the ends of the ligatures were teased separately in a few cases.

1 The effects of age, sex, state of the individual, or other influence of the species of animal or of disease do not form part of this investigation; any reference to such questions has been derived from other sources. 
MEDIUM-SIZED AR'TERIES AND IN 'TENDON LIGA'TURES. 371

III. Macroscopical Appearances of the Arteries aftel Ligation. ${ }^{1}$

\section{Contents.}

In all cases the proximal side of the artery is distended with coagulated blood, modified by changes which will be described further on. In one instance the distal side of the artery also contains a small decolorised clot similar to that found on the proximal side. Up to the seventeenth day the proximal side of the vessel is larger in diameter than the distal side, which is much collapsed and empty (which means evidently that this part of the vessel contained fluid blood during life) ; after the seventeenth day the two segments are about equal, and gradually become more and more contracted.

In the fifth day's specimen (Fig. 1) the clot is dark, and has a convex oblique surface, extending nearly as far up as the first collateral branch above the seat of ligature. This main clot, which fills up the whole lumen of the artery, is capped by a small elongated finger-like process of decolorised clot, which is itself separated from the walls of the artery by a coarsely fibrillated, loose, mottled coagulum. This small digital clot is not axial, but occupies the half of the lumen of the vessel which is opposite to the opening of the collateral branch. It also extends for a short distance above the level of this opening. It is evident from these appearances that the thrombus was not formed all at once.

In the ninth day's specimen (Fig. 2) the clot occupying the proximal portion is smaller than in the previous specimen, but still large. Its surface is convex, but not so much as on the fifth day. Its colour is still dark, there being

1 We have described the macroscopical appearances of our specimens separately in order to render the comparison of our results with those of older writers more easy. 
only a thin layer of laminated decolorised coagulum on its surface. The small additional clots described in connection with the proximal end of the last specimen are

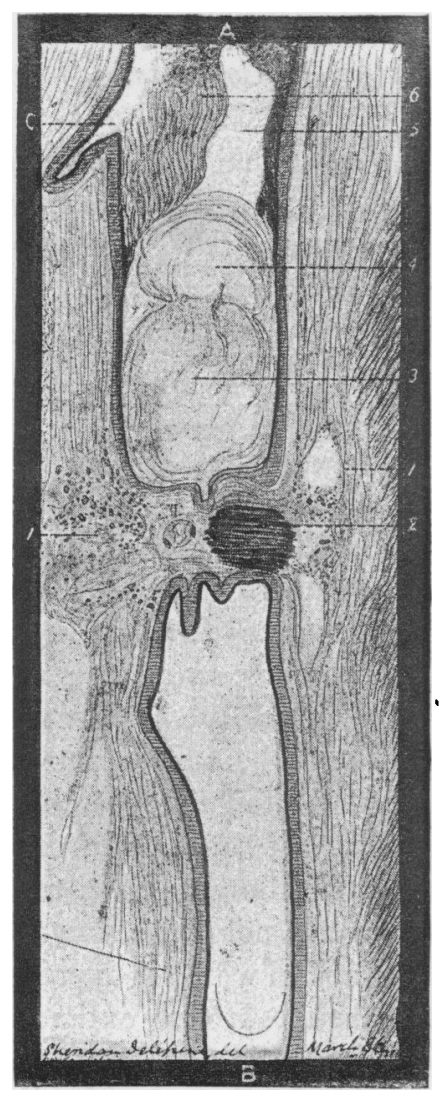

Fra. 1.-A. Proximal end of the artery. B. Distal end of the artery. c. First collateral branch above ligature. 1. Traumatic region. 2. Ligature. 3. Distal or oldest part of the clot. 4. Intermediate portion of the clot. 5. Proximal or digital projection of the clot (recent part). 6. Imperfectly coagulated blood; loose mottled clot. $\times 5$.

not found in this case. Irregular elongated fusiform spaces, occupied by dark recently coagulated blood, are found between the sides of the main clot and the walls of the vessel. 
In the thirteenth day's specimen (Fig. 3) the proximal portion contains a very small decolorised plug, the surface of which is distinctly concave, with a slight elevation at the bottom of the concavity.

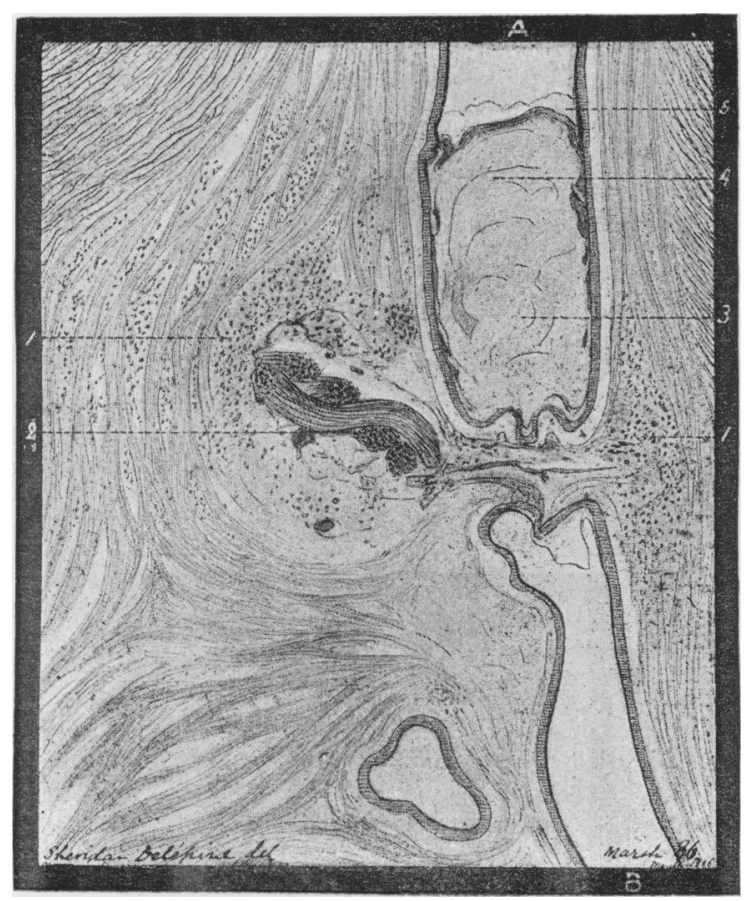

Fig. 2.-A. Proximal part of the artery. B. Distal part of the artery.

1. Traumatic region. 2. Ligature. 3. Distal part of the clot.

4. Intermediate part of the clot. 5. Proximal part of the clot. $\times 5$.

On the seventeenth day (Fig. 4) the plug is very small; its surface is concave ; it is almost completely decolorised, having only a pale brownish colour.

NotE.-The drawings (Figs. 2 and 3) representing the macroscopical appe:rances of the vessels were taken immediately after the first longitudinal section had been carried throngh. This section was purposely made on one side of the middle line, so that the constricted portion of the vessel cannot be seen. This was reserved for the microscopical sections (vide infra). 


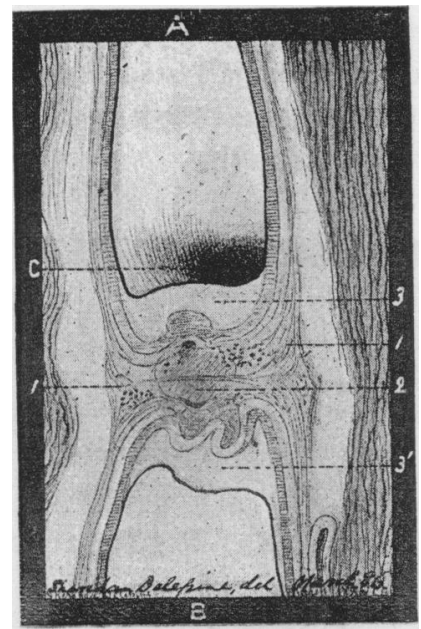

FIG. 3.-A. Proximal part of the artery. B. Distal part of the artery. c. First collateral branch above the ligature. 1. Traumatic region. 2. Ligature seen by transparency. 3. Proximal plug. 3'. Distal plug. $\times \mathbf{5}$.

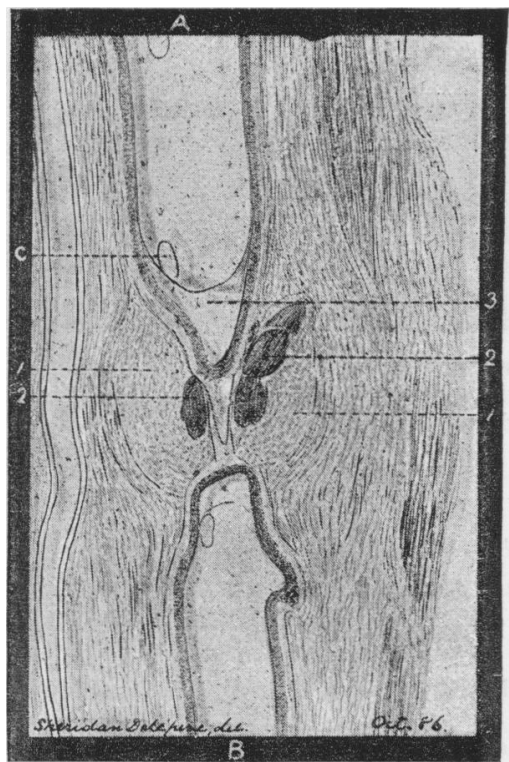

FIG. 4.-A. Proximal part of the artery. B. Distal part of the artery. c. First collateral branch above the ligature. 1. Traumatic region. 2. Ligature. 3. Plug. $\times 5$. 
In the twentieth day's specimen (Fig. 5) the plug is small, decolorised, but not concave, being almost perfectly flat.

In the twenty-third day's specimen (Fig. 6) the plug is a little larger than in the last case, whitish, fibrous-looking, markedly concave-in fact, infundibuliform.

\section{Walls of the Vessel.}

(1) The intima can be almost recognised with the naked eye, and very easily by means of an ordinary pocket lens,

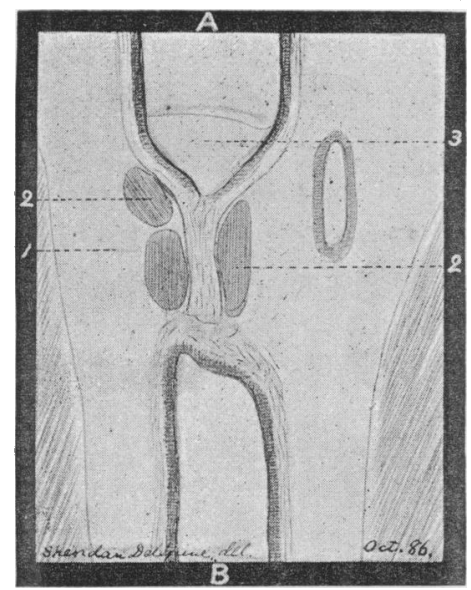

Fig. 5.-A. Proximal part of the artery. B. Distal part of the artery. 1. Traumatic region. 2. Ligature. 3. Plug. $\times 5$.

as a dark (owing probably to its being transparent) thin band, limiting the lumen of the artery both on the proximal and distal portions. In the neighbourhood of the ligature it is puckered, and its divided end curls inward, forming a mammillated projection into the lumen of the artery. This is the case both on the proximal and distal side of the constriction.

(2) The muscularis is also distinct in every case. It looks darker than the adventitia, and seems to be torn as 
well as the intima by the ligature, being apparently almost entirely absent from the constricted region of all the arteries.

(3) The adventitia is distinct in all cases, is folded in the neighbourhood of the ligature, and is the only coat which remains constantly at the seat of ligature. In no case does it show any evidence of a tendency to give way.

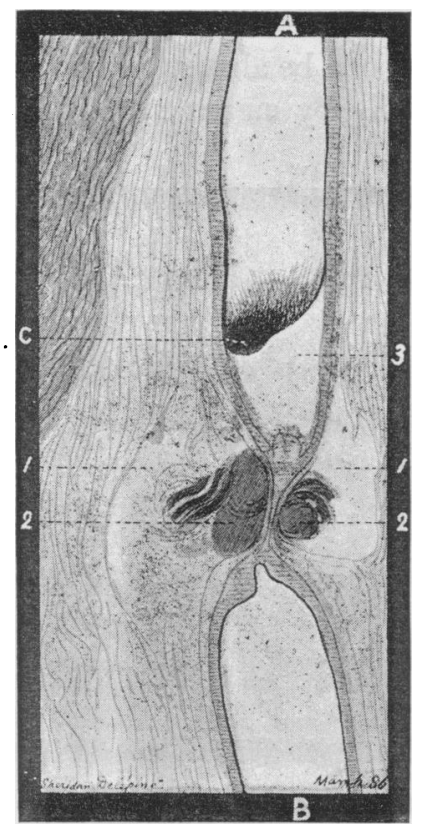

Fig. 6. - A. Proximal part of: the artery. B. Distal part of the artery. c. First collateral branch above the ligature. 1. Traumatic region. 2. Ligature. 3. Plug. $\times 5$.

\section{Perivascular Tissue.}

The tissues adjacent to the artery and ligature are involved over a remarkably small area.

In the fifth day's specimen the affected area could easily be covered by a circle having for radius the diameter of the artery (coats included), and for centre the middle 
part of the constricted portion of the artery (or rather of the side of it in contact with the knot of the ligature).

A circle having for radius twice the diameter of the artery, and the centre of which would be in the midst of the knot of the ligature, would just cover the whole of the affected parts in a section passing through the middle of the vessel nine days after ligature.

After the seventeenth day this area becomes rapidly smaller, the changes giving rise to what seems to the naked eye simply a fibrous thickening of the perivascular sheath.

The changes noticeable to the naked eye are not very striking; they are chiefly due to displacements produced by the incision, the dragging or drawing in of the tissues by the tightened ligature, the projection of the knot on one side of the artery, the accumulation of new material around the ligature (most noticeable in the ninth day's specimen), and finally a certain amount of discoloration and alteration of structural appearances, due at first to extravasation and exudation, and finally to cicatrisation and vascularisation.

\section{Ligature.}

The ligature is very distinct in all specimens, but is more conspicuous in those removed late after ligation than in those removed a few days only after operation. This is due to the fact that after being embedded in the tissues for some time the prepared tendon assumes a dark brown colour. On the other hand, in recent specimens the tissues surrounding the ligature have a darker colour than at a later period.

In the ninth day's specimen the ligature, where it does not form a large mass as in the region of the knot, is almost of the same colour as the surrounding tissues. In this case the parts of the knot do not hold together as well as in any of the others. The tendon has a tendency to split into fine fibrils, so that it is almost impossible to 
obtain a good section of it. The surrounding products hold so badly together that the ligature seems to be quite loose in the midst of a small cavity. In the other specimens it is, on the contrary, tightly held by the inflammatory products, and is distinctly encapsulated after the thirteenth day.

In connection with the ligature knot an interesting appearance is produced in several of the vessels; where the knot presses upon the arterial walls these bulge outward very much less than on the opposite side, where the walls are not so supported. There is, however, no distinct evidence that this absence of support leads to any undue distension of the coats.

The folding of the arterial walls is also more marked on the superficial side of the vessel (that is, the side which is in contact with the knot). This causes a certain obliquity of the plan of section to certain parts of the walls, and leads to an apparent difference of thickness of the walls on both sides, an appearance which must not be attributed to any giving way of the walls on the thin side.

It can therefore be said generally, from a naked-eye examination of the specimens, that in all cases-

(1) The occlusion of the artery was perfect.

(2) The ligature, except in the second case, gave rise to very little irritation.

(3) The ligature showed no tendency to be absorbed.

(4) The walls of the artery did not show any tendency to give way.

(5) The clot as such had practically disappeared after the thirteenth day, and had been replaced by a fibrouslooking plug. 
MEDIUM-SIZED ARTERIES AND IN TENDON LIGATORHS. 379

IV. Microscopical Examination of Specimens.

Fifth Day's Specimen (see Figs. 1, 7, 9, 10).

General remartes. - The occlusion is perfect. The ligature can be distinctly recognised; it is in perfect contact

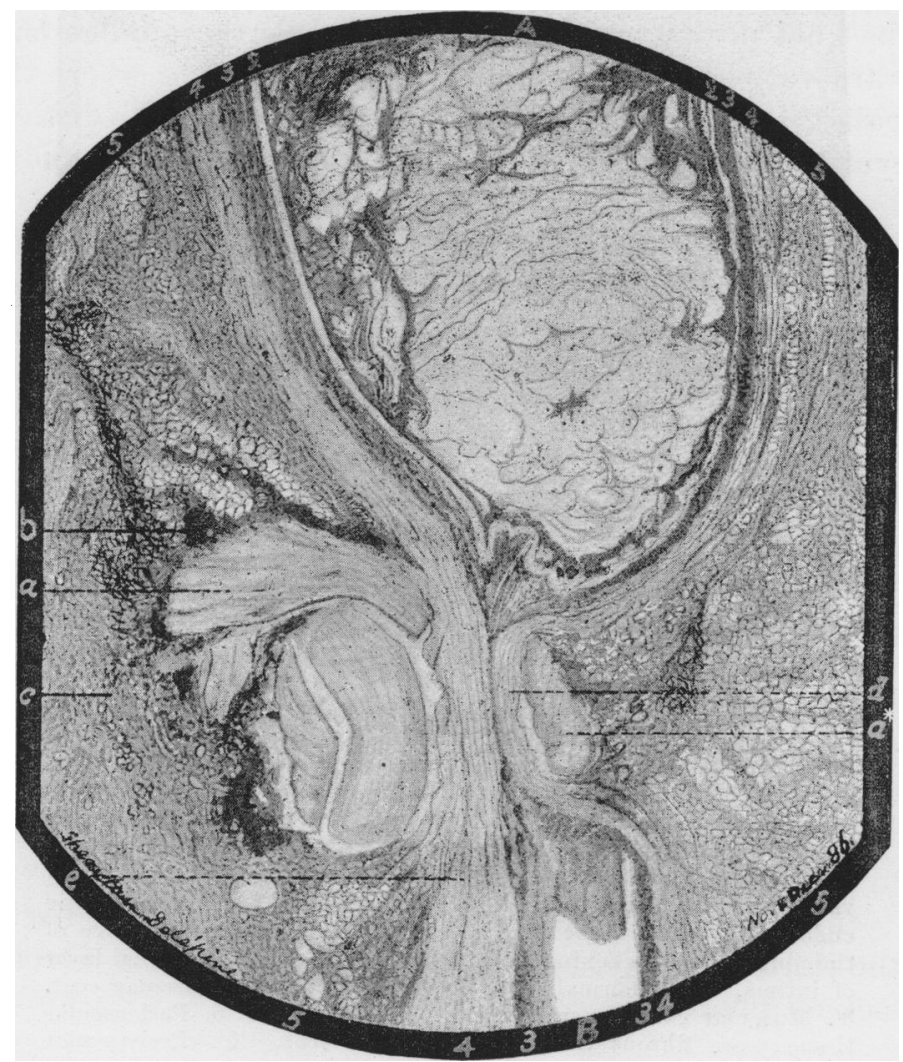

FIG. 7.-A. Proximal part of the artery with the distal part of the clot. B. Distal part of the artery. a. Part of the ligature knot. $a^{*}$. Ligature on the deep aspect of the artery. $b$. Exudation in the traumatic region. $c$. Proliferative zone around the exudative region. $d$. Adventitia in the constricted portion of the artery. e. Infiltrated zone of adventitia. 2. Elastic lamina of intima. 3. Muscular coat. 4. Adventitia. 5. Perivascular tissue. $\times 16$. 


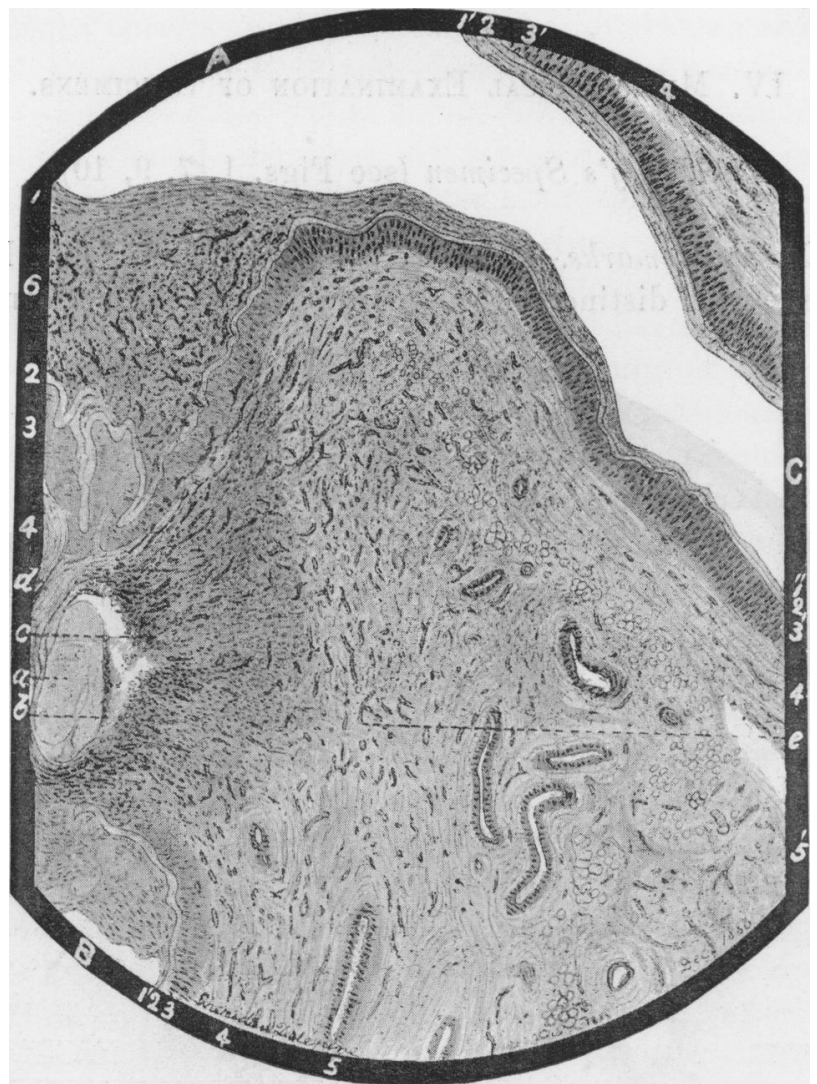

Fra. 8. ${ }^{1}$ - A. Proximal end of the artery. B. Distal end of the artery. c. First collateral branch above the ligature dilated and hypertrophied. $a$. Ligature on the deep aspect of the artery. $b$. Fissure showing the place where exudation was. $c$. Proliferative zone. $d$. Adventitia in the constricted part of the artery. $e$. Perivascular tissue more vascular than normal. 1. Thickening of the endothelial part of the intima covering the proximal surface of the plug. $1^{\prime}$. Thickening endothelial layer. $1^{\prime \prime}$. Endothelial layer of intima, about normal. 2. Elastic lamina. 3. Muscular coat. 3'. Muscular coat hypertrophied. 4. Adventitia. 5. Perivascular tissue more fibrous than normal, fat absent. $5^{\prime}$. Perivascular tissue. 6. Vascularised older parts of the clot containing still blood-pigment. $\times 16$.

1 A little more than half of the vessel is represented here in section. A more complete section is represented semidiagrammatically in Fig. 15 . This incomplete section has been selected because it showed well the collateral branch $\mathrm{c}$. 
with the outer wall of the artery; the external aspect of the ligature is covered with small cells, extending for a short distance into the surrounding tissues. The artery is much larger above the ligature than below, and contains a large clot, the long axis of which is equal to more than twice the diameter of the vessel. The bulging of the artery is more marked on the side of the vessel which is not supported by the knot than on the other, and on the more bulging side the walls look thinner. The walls are pressed inwards by the knot, and owing to that depression some parts of the walls are cut more obliquely than others; this accounts, as already explained, for the apparent difference of thickness observed on both sides of the vessel in microscopical sections.

\section{Contents.}

We have already seen that the part of the vessel extending between the ligature and the first collateral branch above (that is, the part in which the blood is stagnant or nearly stagnant) is almost entirely occupied by a clot. This clot is seen on section to be distinctly composed of several parts.

In this case three parts can be recognised for descriptive purposes, viz. a proximal (or most recent), an intermediate, and a distal (or oldest).

(1) The proximal part forms the finger-like process which we have already described; it is paler than the rest of the thrombus, and on opening the ressel was found surrounded by a mass of imperfectly coagulated blood, somewhat fibrillated or laminated (see Fig. 1). This loose coagulum was very dark ; it nearly entirely disappeared in the course of preparation of the specimen, only a few masses of altered and deeply pigmented blood-corpuscles remaining around the apex of the clot to indicate, so to speak, that the blood there was not quite normal (see Fig. 10). 
The proximal clot itself is composed of several masses separated by thin bands of fibrin, which forms also a thin layer over the greater part of its surface. Near the base of this portion of the coagulum, fibrin is more abundant, and gives that region a somewhat laminated appearance. The most remarkable features of that portion of the clot are the following :

The red blood-corpuscles are little altered, their outline being quite distinct and sharp; but they are paler than normal, with the exception of a few corpuscles forming small additional clumps on the surface of the clot, and having evidently become adherent at some subsequent period.

Leucocytes are seen disseminated all through this proximal thrombus, and are not very much altered. They are more abundant near the surface than in the deeper parts, and in, some superficial spots they are remarkably crowded. In some of the latter places the red blood-corpuscles are evidently breaking down.

Other corpuscular elements are also found, but in small numbers in this part of the thrombus ; these elements have all the appearances of epithelial or endothelial cells, having a large nucleus, frequently oval, vesicular in appearance, staining less deeply than the leucocytes, and surrounded by an irregular cell body. Some of these large nuclei have very little protoplasm around them. There can be very little doubt that these cells are derived from the endothelium of the artery.

Small granules of doubtful natureare also seen in the clot.

The fibrin, as we have already said, forms bands dividing the clot into several parts, but it is found under other forms too. Thus in many places it forms a fine reticulum passing between individual blood-corpuscles. These fine fibrils may run together so as to form the bands or trabe. culø just alluded to. We may add here that in some places near the surface of the thrombus these fibrinous lamellø or trabeculø enclose spaces from which the corpuscles have entirely disappeared. This condition must be 
produced either by destruction, escape of the corpuscles, or accumulation of some amorphous material.

Fibrin may present itself under a third form, not less interesting, namely, that of more or less rounded or oval bodies with branching processes extending between the surrounding corpuscles, the long axis of these bodies being generally but not always parallel to the surface of the thrombus. These stellate masses vary in size, some being very little larger than a red blood-corpuscle, whilst the diameter of others is about thirty or forty times that of a red blood-corpuscle. These dimensions are given so that they should not be thought to be simply degenerating white blood-corpuscles, or even groups of them, or of the so-called blood-plates. In the midst of some of these masses red blood-corpuscles can be distinctly recognised, but in others the blood-corpuscles are replaced by a fine granular material, as if they had broken down. In some of the largest of these masses large vacuole-like spaces are found. These masses are most abundant where the ordinary fibrillated form is least abundant. They do not seem to have any direct connection with white bloodcorpuscles. Nothing corresponding to blood-plates could be discovered in any specimen.

(2) The intermediate part of the clot occupies almost the whole lumen of the vessel ; but it is more or less globular in shape, and has a distinct tendency to separate from the walls of the vessel, especially on one side, as shown by the fissures produced in the endothelium and in the superficial parts of the clot itself. The chief differences between this part of the clot and the proximal parts are the following:

The red blood-corpuscles have retained more of their pigment.

The white blood-corpuscles are differently distributed; they have almost entirely disappeared from the proximal superficial parts, whilst they are abundant in the lateral and deep parts. This distribution suggests the idea that having travelled towards the surface many leucocytes 
have escaped from the clot where such a thing was possible, but that elsewhere they have remained entangled in the clot.

The endothelial cells are more abundant here, and specially in the lateral portions of the thrombus, where they retain in many places their distinct shape.

The fibrin is more abundant near the lateral surfaces of the clot, where, with the leucocytes and with the endothelial cells, it forms a tolerably thick layer. Near the proximal end the arrangement of the fibrin gives to this part of the thrombus a laminated appearance.

The third or distal portion of the thrombus is very analogous to the last.

The leucocytes are, however, more abundant in the central region here than in the last case.

The red blood-corpuscles are somewhat less distinct, more granular, and darker in colour.

The fibrin does not form bands in the midst of the clot; on the contrary, it forms a thick deposit on its surface.

It is evident from the examination of that part of the clot that it must have contracted considerably, remaining connected in several places with the walls of the vessel simply by bands of fibrin. This view is supported by the fact that in the meshes formed by the bands of fibrin at the periphery of the thrombus, masses of red bloodcorpuscles are found which are not so altered as those found in the central parts of the clot, and have evidently been more recently coagulated. We should, therefore, add to our list of the three central thrombi a number of small additional peripheral clots.

Mode of formation of the clot.-It seems from these observations that the clot is not formed all at once, and that after being formed it undergoes numerous-changes due to contraction of its fibrin, migration of its leucocytes, \&c.

It will be evident from our description that what we have called the proximal portion of the thrombus is the one that has been last deposited, whilst the distal was the 
one first coagulated. We can, therefore, by studying in turn these various parts of the thrombus form an idea of the changes which take place successively in the coagulum.

The first changes which take place after coagulation seem, therefore, to be-

1st. The migration of white blood-corpuscles to the surface. Those remaining behind become altered and degenerate.

2nd. The contraction of the fibrin, which causes the formation of channels between the side of the clot and the walls of the artery, and also in some cases in the midst of the clot itself.

3rd. This contraction leads to two things: A. Into the spaces which result from it fresh blood penetrates, and coagulates in its turn. B. Some of the endothelial cells covering the intima become separated from the subjacent subserous layer, and become embedded in the thrombus (Fig. 9).

\section{Walls.}

Tunica intima (Figs. 9 and 10).-In some places the serous layer cannot be recognised, but this may be due to this layer having been separated from the elastic lamina. This seems to have been due to contraction of the clot. In other places between the clot and vascular walls, and generally clinging to the clot in the form of an external dense layer, a number of round and spindle-shaped cells are found. These cells are apparently partly endothelial cells more or less modified, and partly leucocytes which have come to the surface of the clot.

In other places there is, instead of the intima, an irregular layer of cells, evidently resulting from the proliferation of the elements of that membrane. This is well marked but not excessive at the point of occlusion of the artery, where the intima with the subjacent coats is thrown into folds. It is better marked at some distance above the point of occlusion, and specially at some places vOL. LXXIV. 
where the proliferated endothelial cells come in contact with tracts of fibrin.

In some preparations another appearance is also very

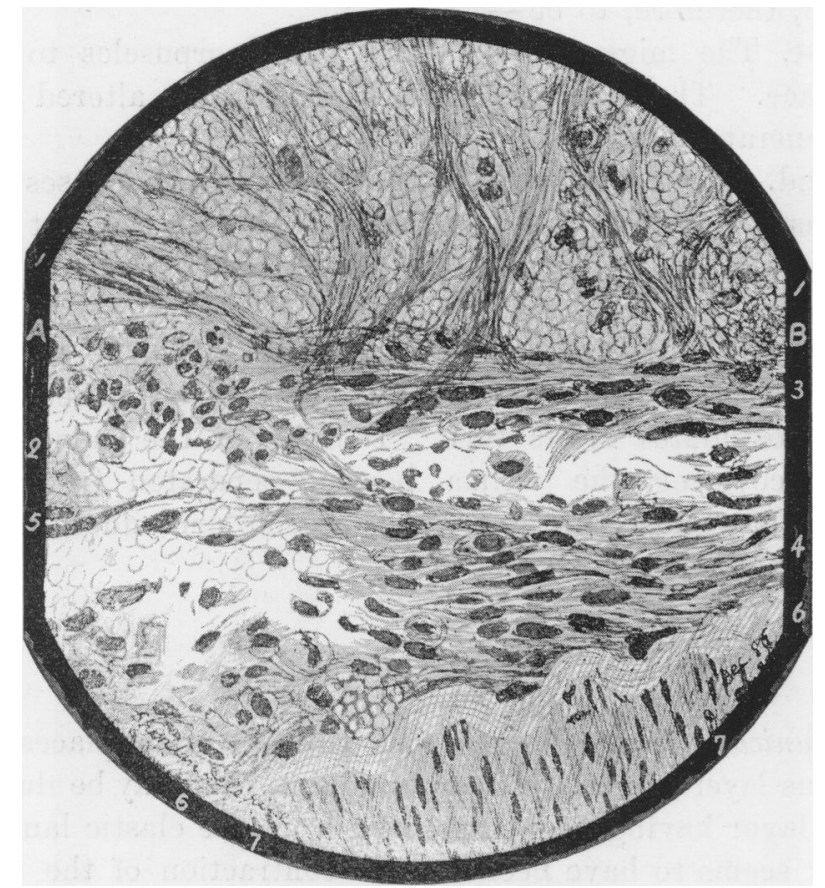

Fia. 9.'-A. Proximal end of ressel. B. Distal end of vessel. 1. Clot (red blood-corpuscles and fibrinous bands). 1'. Clot. 2. Fissure into which fresh blood has penetrated. 3. Proliferating endothelial cells of the intima, dragged away from the rest by the contracting clot. 4. Intima thickened by proliferation. 5 . Loose endothelial cell. 6. Elastic lamina of intima. 7. Muscular coat. $\times 400$.

distinctly marked. The flat cells of the endothelium, or perhaps of the sub-endothelial layer, have proliferated, and remaining attached by one end, project obliquely into the lumen of the vessel, penetrating more or less deeply into the clot.

1 This drawing represents, under a high power, the part indicated in Fig. 10 by $1 x$. 


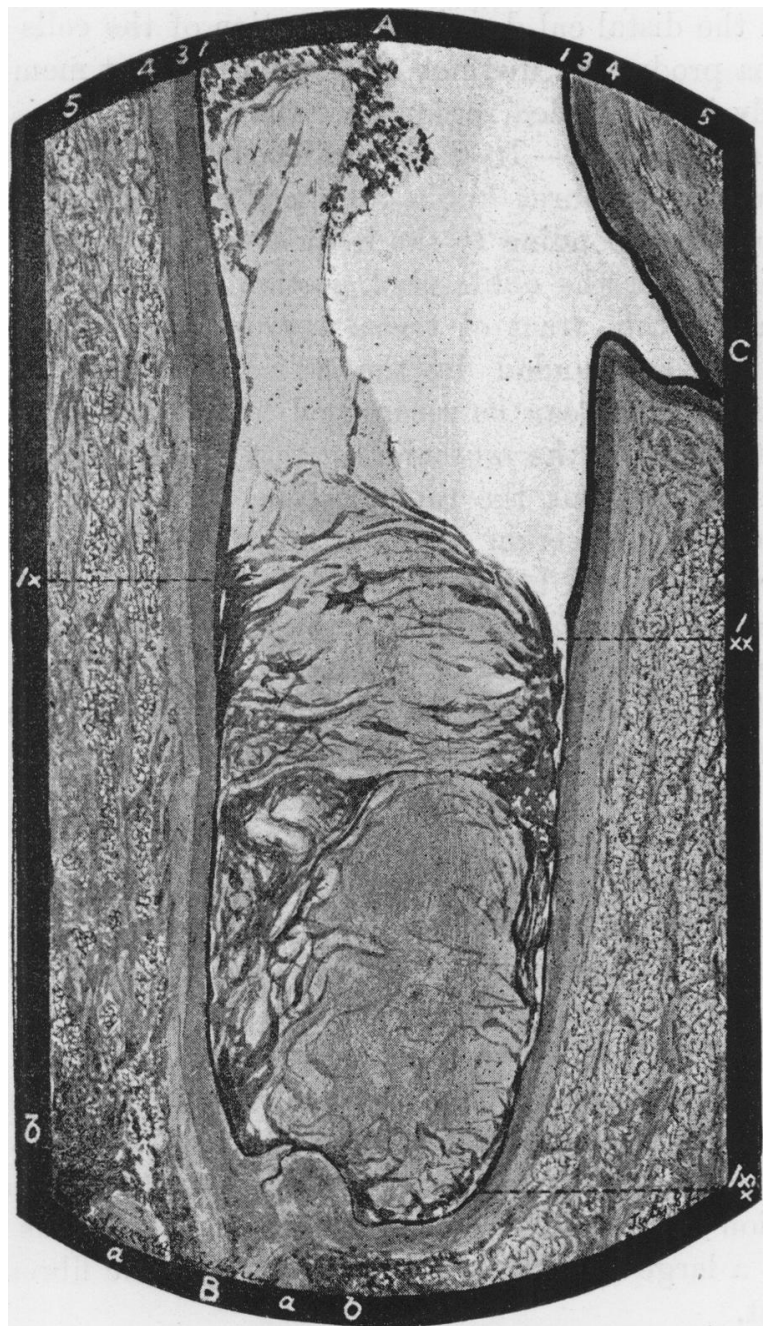

Fra. 10.-A. Proximal part of the artery. B. Constricted part of the artery. $a$. Ligature. $b$. Traumatic zone with exudation. 1x. Tracts of endothelial cells penetrating into the proximal part of the older portion of the clot. 1xx. Endothelial cells of intima, forming layers which split after contraction of the thrombus, and some of which remain adherent to the surface of thrombus. 1xxx. Endothelial layer of the intima, very thin. $\times 12$.

Note.-In Figs. 10, 13, and 15 the outlines are correct, but in order to bring out the intima clearly it has been drawn in black, and in Fig. 10 the contrast is unfortunately not sufficiently well marked. 
In the distal cul-de-sac proliferation of the cells of the intima produces a distinct thickening of that membrane, chiefly in the folded region over the ligature.

Muscular coat.-In the neighbourhood of the ligature the muscular fibres begin to atrophy, especially in the region corresponding to the infiltrated portion of the adventitia. In the obliterated portion of the artery there remains a thin tract of tissue representing the muscular coat, and surrounded by the tunica adventitia. A few muscular fibres can be recognised in that region, but the greater part of the muscular coat is evidently torn up at the same time as the tunica intima, and forms with it a convoluted projection into the lumen of the obliterated artery above and below the seat of ligature.

Tunica adventitia.-This is the only coat remaining in its entirety at the seat of ligature.

The constricted portion of the artery measures in length more than half the diameter of the dilated artery above the point of ligature. The structure of the tunica adventitia in this region is distinctly altered. It stains less deeply than in the other parts. It is less cellular, it is less vascular, and the vessels present are almost obliterated by pressure. The cells are elongated, some of them very small, others rather long and wavy. The intercellular substance is coarsely fibrous, probably owing to the compression of the bundles of white fibrous tissue, the elastic fibres remaining unaffected by pressure. The fibres are straightened and rendered parallel, so that this portion of the adventitia looks like dense fibrous tissue with a large number of parallel coarse elastic fibres in its midst.

At the points corresponding to the proximal and distal borders of the ligature, i. e. in those parts where the pressure of the ligature ceases to exert a direct influence, a very distinct zone of cellular infiltration can be recognised. This zone is very distinct and limited. The cells accumulated in that region are small and irregular in shape.

This cellular zone is easily recognised by the column 
MEDIUM-SIZED ARTERIES AND IN TENDON LIGATURES. 389

of cells separating the fibrous bundles, specially in the outer portions of the coat. Between the most compressed portion of the artery and this cellular region there is an intermediate region where cells seem entirely absent. This indicates that these cells have atrophied, or at any rate that they do not exhibit the usual reactions. The cellular zone corresponds with the point where the ligature ceases to exert its pressure, and where cells of the exudation and infiltrated tissues surrounding the ligature are in contact with the arterial walls.

The adventitia of the proximal side of the artery in the region occupied by the clot is more vascular and cellular than normal. This is true also of the distal side of the artery, but only for a short distance below the seat of ligature.

\section{Perivascular Tissues.}

The vessel is surrounded by adipose tissue in every direction except on the side on which the incision for the purpose of ligaturing has been made. In it there are three important regions to study with relation to the ligature :

A. The traumatic or exudative.

B. The irritative or proliferative.

c. The passive or pressure region.

A. The traumatic region or tract of incision and laceration is very limited, and it includes of course not only the path of the knife, but also the track followed by the ligature needle all round the artery. This region is occupied by exudation products, and the products are arranged so as to form two distinct zones, which, owing to their relations to the artery, can be called internal and external.

The internal, i.e. the one nearest to the artery or ligature, is composed of small round-cells, which are, apparently, badly formed leucocytes, and of the same nature as 
those found in the infiltrated portion of the adventitia. This portion covers the external surface of the ligature, and comes in contact with the walls of the artery on both sides of the ligature, and there a few cells wedge themselves in between the ligature and the adventitia as already described.

T'he external zone of exudation has the appearance of an ordinary fibrinous exudation, being composed of a network of fibrin and of leucocytes. Red blood-corpuscles are also pretty abundant (present also in the internal zone, but difficult to recognise among the deeply stained leucocytes). This region is best marked on the side of the knot, and forms there a triangular area, the base of which lies against the small cells covering the surface of the knot, and the apex, directed obliquely towards the surface of the leg, indiçating the incision line.

B. External to this mass of exuded material the tissues are deeply altered by proliferation of their elements. This layer may properly be called the proliferative region. In this region the normal structure of the tissues is more or less altered by proliferation of the nuclei and of the cells; in the immediate neighbourhood of the space filled with exuded lymph the proliferation has been so active that the original structure of the tissues is almost entirely obscured. The fibrous tissue has become entirely cellular, like embryonic connective tissue; the nuclei of some fat-cells have multiplied, and the connective tissue between them, specially along the course of small vessels, has increased in amount; in some places vessels are seen to be just beginning to form in the irritated connective tissue. These changes are not distributed equally all round the vessel, but extend a little further on the side where the knot is; they also extend along the walls of the vessel, chiefly on the proximal side, more than in other directions.

(c) In the most external layer the tissues are simply altered by the pressure due to the slight accumulation of products in the two regions just described. This zone 
could be called the region of compression or pressure. The most important changes are those found in some muscular fibres which are in a state of hyaline degeneration, a condition which may be in part due to interference with the blood-supply.

\section{Ligature.}

The side of the tendon which is in contact with the artery is almost perfectly even and unaltered, but at both ends of the constricted portion of the artery, where the space between the tendon and the coats of the vessels is gradually widening, small cells form a kind of wedge, penetrating between the artery and the ligature (see Figs. 1, $2,4-8)$. It is in that region that the coats of the vessel show the small-cell infiltration. The side of the tendon most distant from the artery (and therefore in contact with the exudation) is uneven, being apparently absorbed by the small cells.

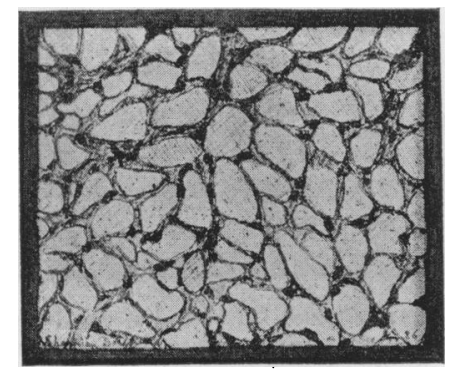

FIG. 11.-Transverse section of a small portion of the ligature five days after the operation. $\times \mathbf{4 0 0}$.

i The structure of the tendon can easily be recognised (Fig. 11), the cells staining readily, but not quite so deeply as the small surrounding cells. The stains are also more easily retained by the cells of the tissues than by those of the ligature. The fibrous matrix may be coloured very 
deeply, but only after prolonged immersion in staining fluid.

The tendinous bands have evidently a tendency to split and become fissured in the direction of their fibres, and this occurs chiefly at their periphery. Owing to this, the surface of the tendon is longitudinally furrowed wherever it is in contact with the exudation surrounding it. The small cells of the exudation penetrate into these furrows (Fig. 12) ;

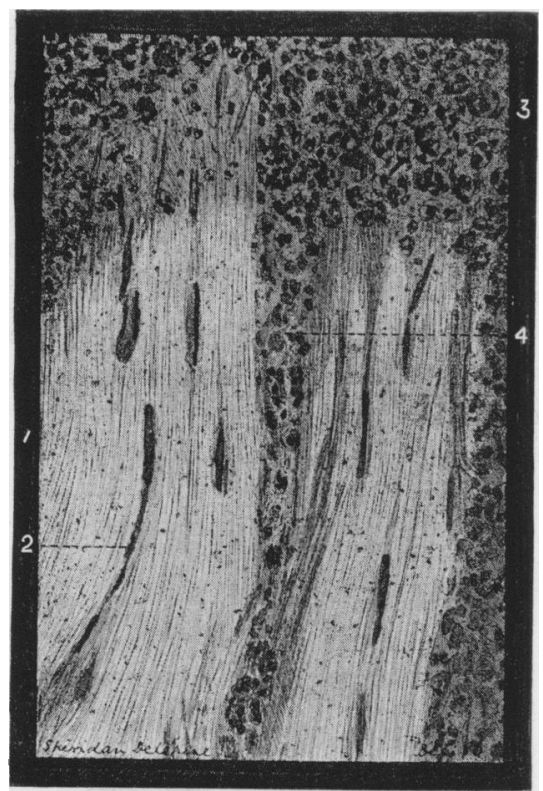

Fra.!12.-Longitudinal section through one of the ends of the ligature five days after operation. 1. Bundles of white fibrous tissue. 2. Tendon corpuscles. 3. Exudation composed chiefly of small degenerated leucocytes. 4. Exudation penetrating into superficial fissures of the tendon. $\times 400$.

and where the plan of section is passing quite near the surface of the tendon, either very obliquely or longitudinally, these small cells seem to form long rows separating bundles of tendinous fibres. To understand the true relation of these cells to the tendon it is necessary to exa- 
mine a transverse section of a tendinous band. At the points where the small cells are in close contact with it the tendon is evidently undergoing a process of slow solution or digestion, but the process is certainly very superficial. Where the ligature is in close apposition with the artery it is less altered than in the parts which are in direct contact with surrounding tissues. This partial absence of changes is more marked on the side occupied by the knot than on the other side, where only one thickness of the ligature separates the coats of the vessel from the inflammatory products.

Ninth Day's Specimen.

General remarks.-The most noteworthy points in this specimen are the extent of tissues involved and the large amount of exudation. The artery is perfectly occluded (see Figs. 2 and 13).

\section{Contents.}

Its proximal end is well plugged by a large clot, the long axis of which is equal to twice the diameter of the artery. This plug, although convex, is much flattened; it has contracted and become further separated from the walls of the artery. Organisation and vascularisation are quite distinct along the sides of the artery, and down to nearly the seat of the ligature.

The distal side of the artery does not contain any clot.

The superficial portions of the clot have disappeared, only the laminated base of the proximal part remaining. The rest of the thrombus, although showing traces of more considerable shrinkage than in the last specimen, has apparently ceased to contract. Large channels have, of course, been formed between it and the walls of the vessel. 
The clot is distinctly becoming organised, or rather is getting gradually absorbed as newly formed connective tissue encroaches more and more upon it. This destruc-

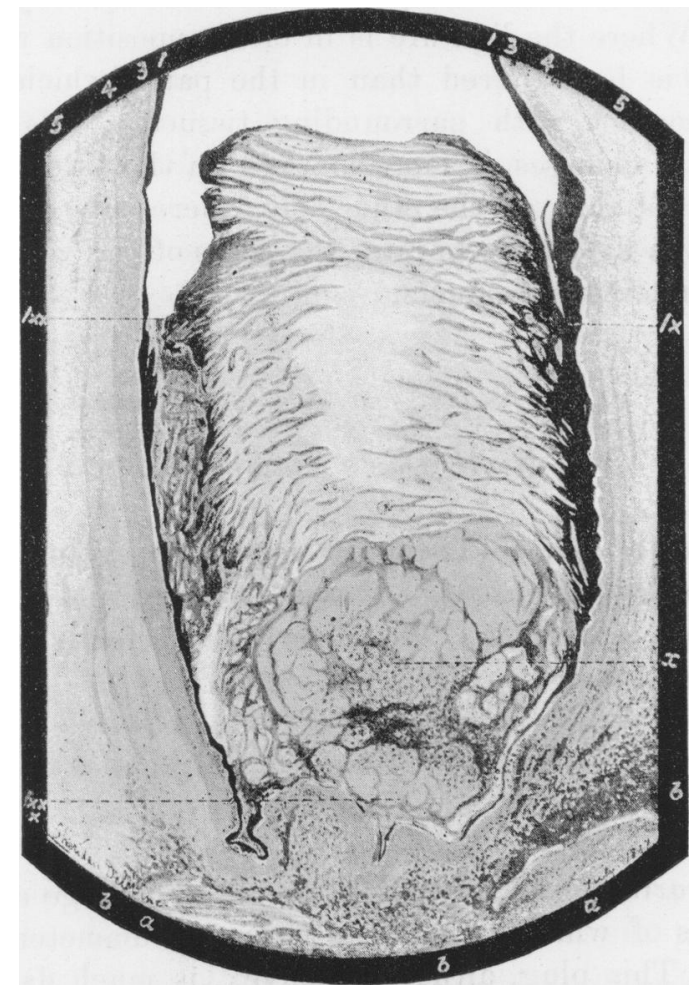

Fra. 13.-Proximal end of the artery above. Constricted part of the artery below. $a$. Ligature. $b$. Inflammatory exudation in traumatic region. $x$. Distal part of the clot infiltrated with leucocytes. 1. Thickened intima. 1x. Thickened intima penetrating into the sides of the thrombus and passing over its surface. 1xx. Thickened intima splitting owing to contraction of the thrombus. 1xxx. Intima much atrophied in the immediate ricinity of the ligature. 3. Muscular coat. 4. Adventitia. 5. Periarterial tis. sues. $\times$ 12. (See note, Fig. 10.)

tion of the clot is most marked in the more proximal portions of the thrombus. In this region the median parts of the clot have still retained nearly all the characters observable at the fifth day, but in the peripheral portions 
there is a mixture of multiplying connective-tissue corpuscles of a more or less fusiform shape, of blood-corpuscles undergoing disintegration (sometimes entirely replaced by small masses of pigment), and of fibrinous débris.

We have said that large spaces are formed at the periphery of the clot, owing to contraction. That such is the case can be easily demonstrated, for in many specimens fresh coagula, in most of which fibrin is in great excess, can be distinctly seen in the midst of the thickened layers of the intima, and around the much altered parts of the distal portion of the thrombus.

Some remarkable changes can be noticed in the leucocytes found in the various parts of the clot. Some of these cells are much smaller than normal, and contain small granular nuclei, which seem to be the result of some degeneration. Other leucocytes apparently run together to form larger compound masses, in which the original cells can generally be recognised.

Endothelial cells are, of course, now abundant, specially at the periphery of the clot, and in those places where the blood has recently penetrated. This is due to desquamation of the endothelium, and is not special to thrombosis due to ligature (one of us has observed a similar desquamation in many pathological states, and also in the vessels of young animals ${ }^{1}$ ). In the distal part of the clot there is a considerable increase of small round-cells, and this increase can be easily shown to be due to the penetration of leucocytes from the tissues surrounding the artery, through the walls of the vessel into the thrombus. These cells are therefore of extraneous origin. This is of great importance, for it gives us the means of testing certain views touching the organisation of the thrombus.

If it were true, as Bubnoff asserts, ${ }^{2}$ that organisation is

I Delépine, 'Trans. Path. Soc.,' 1889, p. 417, \&c.

2 Two recent writers, Ballance and Edmunds, have in the 'Transactions' of this Society, May, 1886, pp. 458, 459, closely followed Bubnoff, and we therefore disagree with them. They say, "The microscope shows that a 
chiefly due to the passage of migratory cells from vessels surrounding the artery, and from the vasa vasorum, into the thrombus through the walls of the vessel, then we should in our specimen find that organisation spreads from where the leucocytes have accumulated; but we find this is not the case, and that organisation begins in those parts where there is no evidence of diapedesis and very clear evidence of proliferation of endothelial cells. This beautiful experiment, worked out by nature, shows in the same artery the effects of two processes, to which the same results are attributed by different observers, and gives a clear demonstration in favour of those who believe in the essential part played by the intima.

\section{The Walls.}

In the intima the proliferation which we had already noticed on the fifth day continues, but the cells take now an arrangement which suggest what is seen when young fibrous connective tissue begins to undergo differentiation. The cells elongate, form tracts which branch in the midst of the organising thrombus, and penetrate even into the parts where the red blood-corpuscles have not yet degenerated. They form thus a distinct network having all the appearances of a capillary network, but with a few exceptions these tracts of cells do not form as yet tubes through which the blood could circulate. On the convex surface of the thrombus the arrangement of these cells is quite different; there they are flattened and form several layers, taking the same appearance cellular infiltration is taking place into the wall of the vessel, around the ligature, and into the clot. . . . By means of these cells the clot near the ligature is decolourised, and, with the ligature, is at last completely absorbed. . . . Riedel is said to have made the inner surface of an artery cohere by multiplication of the opposite endothelial cells without the formation of clot. Of the accuracy of this observation we have grave doubts. Any alteration in the endothelial lining would certainly lead to the formation of a cougulum, and the endothelial multiplication in our specimens is always accompanied by a leucocytic extravasation, the latter apparently being of more importance than the former," \&c. 
as the superficial layers of the thickened intima which covers the walls of the vessel. The muscular coat is torn as well as the intima.

The muscular and adventitious coats are in this case much infiltrated with small cells in the neighbourhood of the ligature, and the specimen shows how easy it is to trace the passage of external products through the walls of the vessels when such a migration is at all important. We would, however, draw attention to the fact that such a migration does not seem to be the general rule, and that in this case we have good reasons to believe that the excessive small-cell infiltration noticeable in the neighbourhood of the ligature was due to some irritant properties of that ligature.

\section{Perivascular Tissue.}

The external aspect of the ligature is covered with a very thick layer of exudation, almost entirely composed of ill-formed small round-cells. These cells are evidently perfectly free, and not held by any solid stroma, so that the exudation must have been of a purulent nature. This was noticeable even to the naked eye. It was difficult to bisect the artery without detaching the ligature from the surrounding tissues. The ligature was evidently lying in a small abscess cavity, and was fixed only by its connections with the artery.

The proliferation zone is also very extensive in this specimen; the fibrous and adipose periarterial tissues are more than half replaced by cellular connective tissue, composed chiefly of small round and spindle-shaped cells with many giant-cells at places. These last cells are chiefly found in the midst of adipose tissue.

\section{The Ligature.}

The ligature is quite distinct, but much more altered than in any of the other specimens, having a tendency to break up into the elementary bundles forming the tendon. 
However, the parts in immediate contact with the artery are scarcely altered at all.

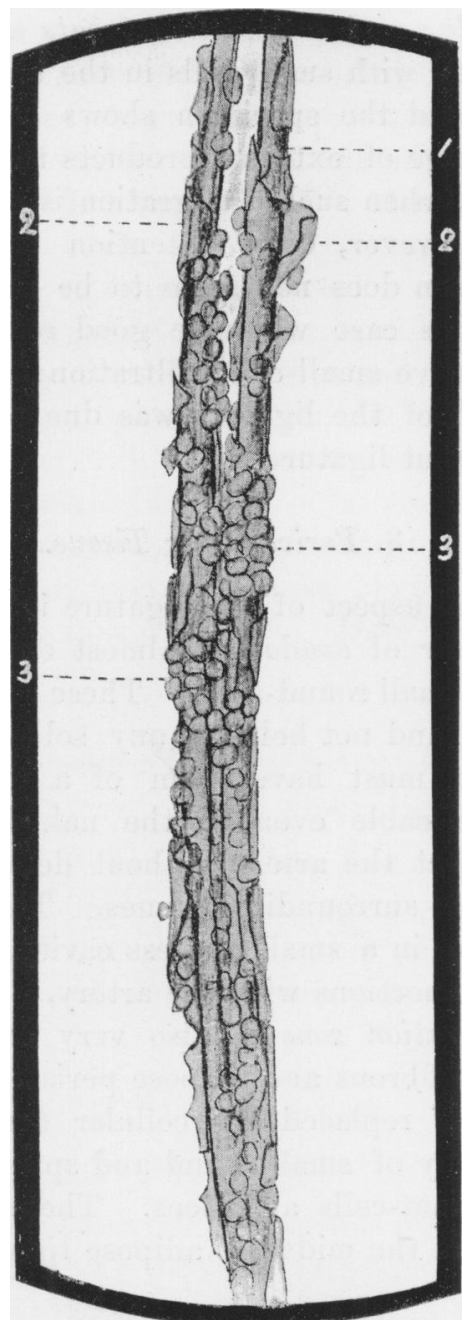

Fro. 14.-1. A tendon fibrous bundle. 2. Exfoliation of the superficial layers of the bundle. 3. Small cells penetrating between the bundles and causing their absorption (phagocytes). Larger cells resembling closely giant-cells or osteoclasts were found in the same situation in some other specimens. $\times 230$. 
It is probable that in this instance the tendon was not so perfect as in the other cases. A few mould hyphæ were found among its bundles, so that it is possible that the ligature was not quite aseptic. It is interesting to notice that, under the influence of the small exudation-cells which had penetrated into the spaces resulting from the splitting up of the tendon, the surface of the primitive bundles is altered. The superficial layers of these bundles are scaling off, and this gives to them a wormeaten appearance. These observations seem to indicate very strongly the importance of homogeneity and perfect asepticity of the ligatures used, but they also show that a certain amount of irritation may be set up without any serious results; indeed, the external appearance of the wound did not indicate in this case that there was any imperfection in the ligature; and, but for the smallcelled infiltration of the clot, there is apparently no indication either of the obliteration of the vessel being interfered with.

\section{Thirteenth Day's Specimen.}

General remarks. The occlusion is complete. The two ends of the vessel are nearly of the same diameter, both being rather large; a plug occupies a small portion of each cul-de-sac quite close to the ligature. These plugs had not to the naked eye the appearance of clots. The collateral branch is not more than $\frac{1}{16}$ inch above the seat of ligature (Fig. 3).

\section{Contents.}

The clot has been replaced on the proximal side by a mass of fibro-cellular connective tissue, evidently continuous with the serous coat of the vessel (see Fig. 13). This mass of tissue is separated from the muscular coat of the artery by the elastic lamina, which is still very distinct. Its free surface is very concave. In the deep parts a very few granular masses of reddish-brown pigment can be 
recognised. This indicates that a small amount of coagulation must have taken place. The depth of the "organised clot" is less than $\frac{1}{16}$ inch on the side corresponding to the collateral branch. In the distal side of the artery there is a smaller mass of newly formed tissue, having exactly the same shape and relations to the walls of the artery as the plug just described. These two plugs seem to be chiefly due to a thickening of the intima.

\section{Walls.}

At the seat of constriction both the inner and the middle coats are absent, as in the previous specimens, above and below this point.

The intima becomes gradually thicker towards the ligature, and is distinctly continuous with the laminated cellular layer covering the concave surface of the plug. The deeper layers are much looser in structure, and, quite near the seat of ligature, contain a few brownishyellow granules of pigment (the remains of a small absorbed clot). In this deeper tissue young vessels are seen, and some have quite a distinct lumen, but they contain no blood. ${ }^{1}$ They extend as far as the elastic lamina, but there is no indication of any passing through that membrane. A few seem to be continuous with somewhat wider channels opening on the concave surface of the plug, but this appearance is so rare that in most sections the proximal part of the clot seems to be nonvascular. The distal plug is undoubtedly due to a thickening of the intima; it contains no pigment, but has otherwise the same structure as the proximal.

The muscular coat is much altered near the ligature; the muscular fibres are atrophied, the interstitial tissue increased. Many small, badly formed cells are also found in this region. All these changes are evidently the indications of what may be called a traumatic interstitial

1 Lumen here and in the following pages, when spoken of with reference to vessels containing no blood, is not meant to indicate an empty cavity, but that of a clear axial substance. 
MEDIOM-SIZED ARTERIES AND IN TENDON LIGATURES. 401

leiomyositis. They are more marked on the proximal than on the distal side.

The adventitious coat exhibits changes very similar to those described on the first specimen.

\section{Perivascular Tissue.}

The exudation surrounding the ligature has very nearly disappeared ; only a very few leucocytes, not even forming a continuous layer, remain on the surface of the ligature. The place of the exudation has been taken by the young round and spindle cells resulting from the proliferation of the periarterial connective-tissue corpuscles. These elements form now two distinct zones.

1. One in immediate contact with the ligature, and composed of small round-cells, spindle-cells, small giantcells, a few fibres, and small vessels beginning to form.

2. Another, more external and narrower, but more extensive, composed of large und small giant-cells, large round, spindle-shaped, and irregular cells with large nuclei, bundles of fibrous tissue, and a few fat-cells undergoing atrophy or retrogressive changes. The tissue forming that region has nearly the characters of myeloid sarcoma. This embryonic tissue extends in the direction of the incision, and is therefore more abundant on the knot side than on the other. A few hairs, evidently accidentally enclosed in the wound, are found unaltered and embedded in the new tissue, apparently giving rise to no special changes.

Some of these hairs are covered with a distinct layer of small cells.

\section{Ligature.}

The ligature itself is practically unaltered ; its external surface is hardly more uneven than in the first specimen; the forming young vessels noticed in the inner part of the proliferative region hardly reach the surface of the tendon.

vOL. LXXIV. 


\section{Seventeenth Day's Specimen.}

General remarks.-In this specimen, as in the ninth specimen, there are very marked inflammatory changes. The occlusion is perfect (Fig. 4).

\section{Contents.}

Both the proximal and the distal portions of the artery are occupied by vascular young connective tissue. Groups of decolorised red blood-corpuscles can be recognised in the proximal plug, which is evidently taking the place of the original clot, which has now almost entirely disappeared.

The proximal plug is composed, as in the last case,1st. Of a non-vascular layer of flattened cells lining the free concave surface of the plug, and continuous with the endothelium of the thickened intima. 2nd. Of a deeper part occupying the rest of the proximal cul-de-sac, and composed of bands or ramifying tracts of spindle or branched cells. Most of these tracts are young vessels and have a distinct lumen, but as yet contain no blood. Between these tracts small clumps of decolorised and very indistinct red blood-corpuscles and also granules of pigment are found. These are the only remains of the original blood-clot.

In the distal plug (which in this case is larger than in any other case) the thickened tunica intima is continuous, as in the proximal plug, with the new connective tissue. This connective tissue presents the arrangement described above; the young vessels do not, however, present so distinct a lumen, and the tracts of cells are separated by a hyaline material which contains neither red bloodcorpuscles nor blood-pigment.

Although the free superficial layers of both plugs are non-vascular, generally speaking, a few pretty large vessels extend through them in or near the axis of the vessel. The meaning of this arrangement will be clear 
after the description of the twenty-third day's specimen has been given.

\section{Walls.}

The infiltration of the arterial walls is very marked, chiefly on the distal side. The changes in the intima have been described above. The muscular fibres of the media are much atrophied; young vessels begin to extend into the degenerated parts, both from the intima and the adventitia. The adventitia is much infiltrated with cells in the neighbourhood of the ligature.

\section{Periarterial Tissues.}

The ligature is still partly covered with exudation products, but in many places the proliferative zone is now in contact with it. This zone is much more extensive in this case than in the last, and in that respect the specimen bears a strong resemblance to the ninth day's specimen. The adipose and fibrous tissues are being replaced by young connective tissue as in the last specimen. This process is extending to the muscular tissue in the neighbourhood, which shows very well the lesions resulting from interstitial inflammation.

\section{Ligature.}

The ligature itself is more altered than in previous specimens with the exception of the ninth day. The tendon seems to undergo a partial process of slow solution wherever it comes in contact with the small cells surrounding it, and penetrating into the fissures or spaces existing in the tendon itself or between the twisted portions of the knot. 


\section{Twentieth Day's Specimen.}

General remarks.-There is nothing special in this specimen, which in many respects is similar to the following one. The occlusion is perfect (Fig. 5).

The inflammatory tissue changes are comparatively slight. The line of incision is occupied by cicatricial tissue composed of spindle-shaped cells. The proliferative region surrounds the ligature, which is thus encapsulated. But there is apparently no adhesion between the new tissues and the ligature, which can be easily separated from them. The giant-cells are rather less conspicuous in this case than in the ninth and thirteenth days' specimens. The most striking feature of this stage is the abundance of evidently newly formed vessels in the periarterial tissues.

\section{Twenty-third Day's Specimen.}

General remarks.-The occlusion is complete. Most of the changes which we have to describe now can also be recognised on the twentieth day; but the study of the artery on the twenty-third day is advantageous, as by that time the absorption of the clot is completed, and the beginning of the true vascularisation of the plug of fibrous tissue replacing the clot has become evident (Figs. 6, 8, 15).

\section{Contents.}

The proximal side of the artery is occupied by a plug of fibro-cellular tissue; the length of that plug is not greater than the diameter of the artery. The surface is distinctly concave, almost infundibuliform, and on one side is flush with the opening of a collateral artery, which is evidently much dilated. This plug is composed of two distinct parts, a superficial and a deep part. The superficial, which is continuous with the thickened intima of the 
patent portions of the artery, is not vascular, with the exception of a few vessels passing to the deeper layer.

The thrombus itself is now represented by a few small masses, a brownish-yellow pigment lying in the midst of the newly formed connective tissue forming the deeper part of the plug, specially in those parts where there is much clear interstitial substance between the newly formed vessels. A few dark masses of different appearance remain also in the most distal part of the clot; and, although their nature is doubtful, it is probable that they are simply remains of partly absorbed masses of fibrin.

The clear material, forming a kind of ground-substance between the tracts of cells representing embryonic vessels, seems to be in part a product of the destruction of bloodcorpuscles and fibrin. The masses of pigment above described have a special distribution, which will be better understood after considering the intima.

\section{Walls.}

At first sight the tunica intima seems to have simply become thickened, and that more in the immediate neighbourhood of the ligature, and less at some distance from it, causing thus the lumen of the occluded artery to take an infundibuliform shape. This of course goes entirely against what we have described in the previous cases, and seems to support the views of certain writers. ${ }^{1}$ The meaning of the appearance can, however, be easily arrived at by a consideration, 1st, of the form and degree of organisation found in the various parts of the organised thrombus; and 2nd, of the distribution of blood-pigment in it (Fig. 15).

The proximal depressed surface of the plug is seen to be formed by several layers of flattened cells, in the midst of which branching embryonic vessels are not found. We have seen that such a layer of cells was extending over the convex surface of the clot at an earlier stage.

1 Cornil and Ranvier. 
Beneath that thickened endothelium we find, on the contrary, a somewhat loose tissue, in the midst of which

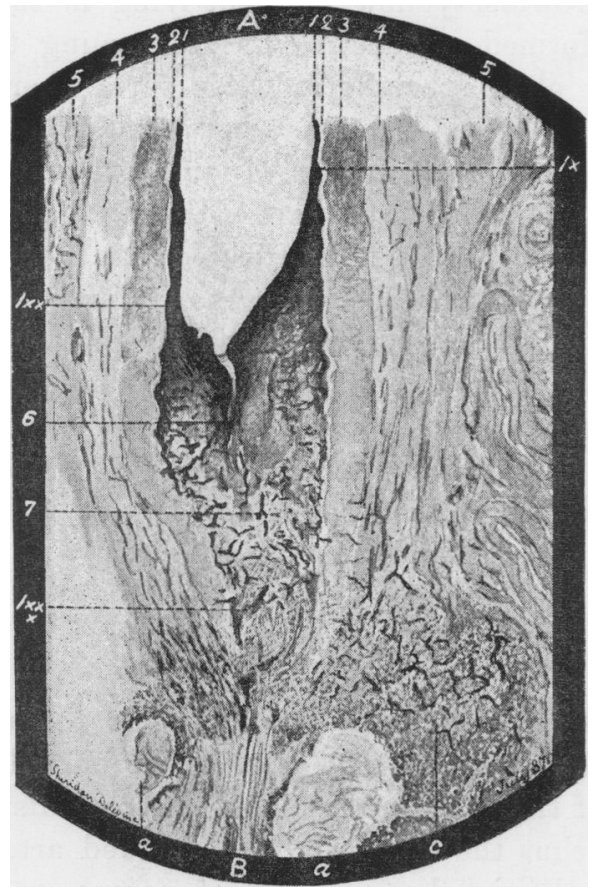

Fig. 15. ${ }^{1}-A$. Proximal end of the artery. B. Constricted part of the artery. c. Young connective tissue with embryonic vessels in and about the traumatic region. $a$. Ligature. 1. Thickened intima. 1x. Point corresponding to the level of the clot before absorption, and from which the endothelium began to spread over the clot. The acute angle of reflexion has now been replaced by an obtuse angle owing to the collapse of the central parts, following absorption of the clot. 1xx. See explanation under 1x. 1xxx. Original endothelial and subendothelial layers of the intima indistinct in the neighbourhood of the ligature. 2. Elastic lamina. 3. Muscular coat. 4. Adventitia. 6. Indication of a central canalisation of the plug. 7. Pigmented débris of clot almost entirely replaced by young connective tissue with embryonic vessels. $\times 12$. (See note, Fig. 10.)

1 This section is slightly oblique, and does not pass through the axis of the vessel (which was tortuous) except at the point of constriction, so that the conts a little above the ligature look thicker than if they had been cut mesially. 
numerous embryonic vessels with a distinct lumen are seen branching ; and this form of tissue we have also seen, at an earlier period, to take gradually the place of the deeper parts of the thrombus.

As to the pigment, we find it only in this loose tissue, both on the deep aspect of the dense layer of flattened cells described above, and in the more distant parts of the thrombus. We come, therefore, to the conclusion that the layers of flattened cells lining the funnel-shaped depression at one time were covering the convex proximal end of the thrombus, and that it has been drawn in, so to speak, owing to subsequent absorption of the subjacent thrombus. As this membrane was attached to the sides of the artery, it must remain fixed there, so that only the central parts could give way.

The muscularis is now much altered.

The muscular fibres are now in a state of atrophy, and fibrous tissue takes their place. In several points there are indications of vessels penetrating from the tunica adventitia into the muscular coat, and in some places some of the young vessels formed in the organised thrombus seem to pass beyond the elastic lamina and penetrate into the coat.

These changes are most marked in the immediate neighbourhood of the seat of ligature, and have probably given rise to the opinion that the vessels formed in the organising thrombus were due to an extension of the vasa vasorum into the clot through the tunica media and the intima.

The alterations of structure of the adventitious coat described in relation with the fifth day's specimen are almost quite as distinct in this case. There is, however, a marked increase of vessels. Some of these vessels are evidently enlarged and hypertrophied vasa vasorum, but a great many others are newly formed vessels extending from the periarterial proliferative zone.

The constricted portion of the artery is composed, as in the first specimen, of very little more than the external 
fibrous coat of the artery, no distinct trace of the muscular coat being found in the constricted portion of the artery.

\section{Periarterial Tissue.}

There is no trace of exudation around the ligature, but the cells of the proliferative region are now in close contact with the tendon, and in the most external portions of the knot many large giant-cells are found. However, the new tissues are not connected structurally with the ligature. The only place where the ligature seems to be at all firmly connected with the tissues is where it is in contact with the walls of the constricted artery. Even then the adhesion seems to be due to the effects of pressure, for no indication of any inflammatory reaction is found in this portion of the arterial walls (in any specimen), and on the other side there is no trace of any alteration in the ligature itself.

The proliferative region is now rather small and well defined; fatty tissue has disappeared from that region, which is now made up of round, spindle, and giant cells. The giant-cells are now found all through that zone, and many of them are lying against the ligature in the same way as osteoclasts might lie against bone trabeculø (they are found all through this tissue of new formation). This seems to indicate that they are results of the irritation of cells. They are quite comparable to phagocytes, and all the cells of the same nature which have been described under various names by various authors during the last forty years. In the midst of the proliferative zone, which therefore must have filled up the space originally occupied by the exudation, portions of hairs and even of sponge are found ; they are embedded in the new cellular tissue, and do not seem to cause much disturbance by their presence. The giant-cells are apparently a little more numerous in their neighbourhood, and the 
spindle-shaped cells are arranged more or less concentrically around them.

The most important features of this specimen are certainly increased vascularity of the periarterial tissues, and the distinct evidences there are of an extension of the periarterial and intra-arterial embryonic vessels towards each other, this process evidently leading to the establishment of a new set of vessels through the degenerated portions of the walls of the obliterated vessel.

\section{Ligature.}

The ligature in all the other cases is in perfect contact with the adventitia in the constricted portion, and when it is in contact with the artery it does not seem to have undergone any change. On its outer aspect it is in many places somewhat irregular, but on the whole the ligature is in this case much less altered than in some of the precedent cases.

\section{Summing UP and Interpretation of the Changes OBSERVED.}

The operation for ligation, when completed under the conditions described in this paper, results in-

1st. The presence of a foreign aseptic body round the walls of the artery at the point of constriction.

2nd. A solution of continuity in the periarterial tissues.

3rd. The laceration of the two inner coats of the vessel. ${ }^{1}$

1 This solution of continuity, which in healthy arteries is obtained by using a definite amount of strength, must occur in diseased arteries under very different degrees of pressure, according as the inner coat is more or less brittle and the middle coat contains more or less elastic elements. The larger a vessel the less is its middle coat liable to rupture. The more atheromatous and calcified, the more are the middle coats likely to give way, even before the artery is completely constricted. Admitting that it were judicious to tie a calcified artery, it is evident that the calcified plate found in the deeper 
4th. The compression of the external coat.

5th. The complete obliteration of the lumen of the artery and the production of two culs-de-sac, a proximal and a distal, which have the same walls as the vessel itself, even in the region where the inner coats are ruptured. This effect is brought about by the contraction of the muscular coat, and possibly to a certain extent by the elasticity of the elastic lamina, which leads to closure of the openings of the divided intima and muscular coats. In vessels of the size used in our experiments the contracting coats do more than meet; they become heaped up in the axis of the vessel, so as to form a small projection into the cavity of the artery on both sides of the constricted region; this makes occlusion doubly safe. The opposite sides of the adventitia being brought into close apposition by the pressure of the ligature, the fissure indicating the cavity of the vessel can be entirely discarded. Such is the state of the artery immediately after tight ligation.

I'he effects of the operative lesions just described are the following :

A. 1st. A clot forms in the proximal cul-de-sac, and sometimes in the distal one also. ${ }^{1}$ The proximal clot extends as far as the first collateral branch above the liga-

parts of the intima would break and tear the remainder of the intima long before the lumen was completely obliterated. It is, therefore, evident that the tearing of the inner coats, which we describe here as the result of a method of ligation, would occur, whether it were desired or not, in the case of many diseased vessels.

1 We know, from the experiments of other observers, that when an artery is tied with a loose ligature, even when the lumen is apparently entirely occluded (without rupture of the inner coats), a thrombus forms both on the proximal and distal sides of the ligature. There is, therefore, apparently some marked difference in the extent of thrombosis occurring after tight and after loose ligation. It is to be noticed, however, that in the latter case a thin strand of coagulated blood extends between the proximal and the distal thrombi, and from what we know of coagulation it is quite likely that so long as there exists a tract of blood between the two culs-de-sac, thrombosis beginning in one of them would extend to the other through that intervening tract. 
ture. It is not formed all at once ; coagulation evidently begins at the point where the coats are divided, and then extends gradually (though not without intermissions) as far as the collateral branch, and even beyond it on the side of the vessel where the current of blood is slowest.

2nd. Whilst the clot is formed within the vessel, lymph and blood fill up the gaps produced by the knife and the needle, and coagulate also.

3rd. All the parts of the vessel compressed by the ligature are rendered bloodless and incapable of vital reaction. This is a result of pressure, and would occur whether the inner coats were or were not divided. ${ }^{1}$

B. The lesions just described lead to further changes in the walls of the vessel and in the periarterial tissue.

1st. Proliferation of the cells of the intima near the seat of ligature and as far as the clot extends; the amount of proliferation is, however, not uniform, and depends on several circumstances. Thus, when there is no thrombosis, it is at its maximum near the place of constriction, rapidly diminishing towards the heart or towards the extremities. When, on the other hand, there is a thrombus occupying the whole lumen of the vessel, and therefore preventing the access of fluid blood to the endothelial surface of the intima, the proliferation is soon arrested in the parts thus covered, and attains its maximum near the surface of the clot which is bathed by the circulating blood. As the proximal cul-de-sac of the artery is after tight ligature always occupied by a clot, except when the ligature has been applied just below the opening of a collateral branch of some size, the growth of the intima takes place mostly at the point of junction of the proximal surface of the clot and of the walls of the vessels, and therefore at a distance from the seat of ligature equal to the length of the clot itself. When coagulation is incomplete, and an axial thrombus is formed, pro-

1 If, as alleged, the occluding ligature actually causes greater pressure than the tight ligature, this effect of pressure would still more interfere with the nourishment of the walls when the loose or occluding ligature is used. 
liferation of the cells of the inner coat takes place near the seat of ligature as if there was no thrombus at all.

2nd. Inflammatory changes of the same kind but of much less importance occur in the connective-tissue elements of the adventitious coat on both sides, and in the immediate neighbourhood of the ligature, and also to a still lesser extent in the muscular coat. These changes seem to be generally slightly complicated by an exudative infiltration. The small cells (leucocytes) forming this exudation sometimes penetrate the clot in great numbers, but they have, as we have shown, no share in the organisation of the clot, and should not receive the misleading name of plastic exudation.

3rd. In the periarterial tissue inflammatory proliferation also occurs all round the traumatic region.

c. All the changes which we have described so far are already completed or have distinctly begun before the fifth day after ligature. The following changes result from the extension of the elements resulting from the proliferation of the intima and periarterial tissues into the decaying clot, arterial walls, and the periarterial inflammatory exudation, which undergo gradual absorption.

The intima extends over the surface of the clot and penetrates into its sides. At the same time the clot shrinks, and its proximal part is rapidly absorbed by the young connective-tissue corpuscles invading it. The distal parts of the clot are less altered at first. The endothelial cells covering the surface of the clot form a dense stratified layer ; the deeper cells proliferate so as to form tracts of spindle-cells; these tracts are young vessels. The whole clot is permeated by such a network before the end of the second week after ligature. After this it seems probable that the artery can be considered as safely and permanently plugged. The clot is getting more and more absorbed, and its proximal surface sinks in, with its lining of endothelial cells. This surface is at first concave, then funnel-shaped, and thus becomes more and more approximated to the walls of the vessel. This superficial 
layer is separated from the muscular coat by the deeper connective tissue containing young blood-vessels, which have now a lumen though they contain no blood. Ultimately these young vessels continue to extend by multiplication of their cells through the muscular coat, and meet those extending from the tunica adventitia and the periarterial tissue. All this is clearly indicated at about the end of the third week.

D. We have made it clear that we did not believe in the existence of a true circulation in the clot for at least three weeks after ligation. We admit that fresh blood penetrates into fissures produced by contraction of the clot, but we contend that this is not equivalent to a true circulation, and we speak of it as a vacuolation or a false vascularisation.

In the course of the second week after ligation embryonic vessels become evident in the tissue resulting from the proliferation of the intima, as well as in the periarterial inflamed tissues. In the clot, however, these vessels, which are at first solid, even when they have a distinct lumen, cannot serve the purposes of circulation before they communicate with other vessels which may serve as outlets. These vessels, although temporarily useless, are nevertheless vessels, and the vascularisation at this stage might be called potential.

After the third week, owing to the inosculation of intraand extra-arterial young vessels through the gradually degenerating muscular coat, circulation becomes possible, so that effective vascularisation can be said to exist after that date.

E. The ligature has during the whole of this time got gradually but very slowly absorbed. At first it was embedded in the exudation products. After decay and absorption of these the inflamed periarterial tissues come in direct contact with it, and form a distinct capsule for it. By the end of the third week the kangaroo tendon ligature practically supports the walls of the vessel as efficiently as on the first day. 
F. The changes which follow are only indicated in our specimens. They are-

1st. Contraction of the newly formed connective tissue, causing obliteration of the old vessel.

2nd. Complete absorption of the ligature, and probably of all the parts of the vessel which have died from the interruption of their blood supply by the pressure of the ligature or interference with the vasa vasorum.

3rd. Dilatation of the large collateral vessels above the seat of ligature.

4th. Owing to the formation of vascular connective tissue round the ligature a certain amount of circulation may be reestablished between the proximal and the distal ends of the ligatured vessel through the small newly formed vessel.

5 th. The vasa vasorum of the distal part of the vessel may also be supplied with blood by anastomosis with small branches derived from the collateral branches of the artery above the constriction.

Hogson had formerly remarked that at first, $i . e$. before the complete dilatation of the collateral branches of some size, circulation is carried out by innumerable small vessels, and that the dilatation of the smallest was more marked than that of the largest.

All the changes we have just described are those which can be observed in a medium-sized healthy artery. We insist upon the fact that we have not thought it desirable to introduce into this investigation a consideration of the effects of the size, situation, age of arteries, or of the species of animal used for experiment. But by comparing our results with those of other observers who have also applied tight ligature to various healthy arteries of several animals, such as the dog, the sheep, the horse, and even man, we have been able to satisfy ourselves that our practical results were in agreement with those of our predecessors. Our chief aim now, however, is not so much the discussion of the question in all its practical details, as the consideration of the nature of the processes which lead to the occlusion of a vessel the inner 
coats of which have been divided by ligation. These results are comparable only with those obtained on similar bases by other methods, such as, for instance, those which do not imply division of the inner coats. The discussion that follows must therefore be considered as one of principle, and not as one of details. We, however, know from a careful study of the subject that the principles which we support, and which have been supported by the great majority of surgical authorities since the time of Jones, are more generally applicable in practice than the opposite principles. Our investigation seems to us to give a large number of physiological facts in support of this view. It must be remembered that we have had all these facts before us for more than five years, and we have seen no reason to withdraw any of the statements made by one of us in 1887, and in which we both concur.

\section{Criticism of Views held by other Observers. ${ }^{2}$}

1. Anatomico-physiological.

The pathologists and clinical observers who have studied the subject from this point of view have devoted the greater part of their attention to the ways in which, 1st, the temporary mechanical obliteration of an artery brings about the permanent organic transformation of the vessel into an impervious cord; 2nd, the interrupted circulation is re-established by new channels; 3rd, the ligature is either expelled from the tissues or destroyed.

Many other points have been discussed especially by

1 Delépine, ‘ Brit. Med. Journ.,' Aug., 1887.

${ }^{2}$ In this discussion we will not allude to observers who have written during the last decade, except for the purpose of discussing some practical points. The views which we advance here regarding the changes occurring in the thrombus and walls of the vessel are exactly the same which one of us had already brought forward in 1887. They have since been confirmed by other observers. They differ considerably from the views then supported by Mr. Ballance and Dr. Edmunds. 
practical surgeons, but the three just mentioned are those on which, in principle, the operation can be said to rest.

The first writers, such as John Hunter, Jones (1805), Hogson (1815), Stilling (1831), Hasse (1846), Rokitansky (1852), Weber, Billroth, \&c., seem to have studied chiefly the contraction and retraction of the divided coats, and the phenomena evidenced by the clot, such as the arrangement of its layers, its vascularisation, its regressive changes, \&c. The clot was generally supposed to take a part quite sui generis in the process of occlusion. The fact that the ligatures were allowed or desired to ulcerate their way through the coats of the vessel brought about changes of a special nature. The destruction of the coats of the vessel at the seat of ligature led to the formation of a mass of young connective tissue, which rapidly took the place of the destroyed portion of the artery, and the production of new vessels in that region did often bring about results which were common subjects of discussion among the pathologists and surgeons of the day. Inasmuch as the suppuration and ulceration led to the destruction of a portion of the vessel, the formation of extensive plugs above and below the seat of ligature was desirable to prevent the occurrence of secondary hæmorrhage. Hence the importance attached to the formation of the thrombus, to the retraction and contraction of the divided coats, to the distance of the ligature from the first collateral branch above, \&c.

After the introduction of the antiseptic method and of aseptic ligatures, the conditions of the operation became so altered that some jumped to the conclusion that everything occurring after ligature under the new conditions must differ wholly in principle from what had been previously supposed to be the case. This phase of opinion, favoured by the very narrow view which Cohnheim had taken of inflammatory processes, led to the publication of ideas such as those of Senftleben (1879), the chief merit of which has been to create adverse criticism and to lead to further experiments. 
Despite the passing fashions resulting from the injudicious application of true principles, the knowledge of the changes occurring in vessels after ligature has been growing slowly, owing to the patient and sound work of the observers already mentioned, and also more especially of Virchow (1862), Waldeyer (1867), Bubnoff (1867), Thiersch, Cornil and Ranvier, Durante (1872), Zahn (1875), Pitres (1875), Riedel (1875), Quincke (1876), Schultz (1877), Auerbach (1877), Baumgarten (1876-7), Tillmanns (1879), Shakespeare (1879), Raab (1879), Foà, Pfitzer, Arnaud, Szuman, Hamilton (1881). During the last decade several other workers have continued the work begun by those just mentioned. Many other names might be included in the list.

A. Coagulation.-Virchow and Rindfleisch attributed the formation of the thrombus chiefly to stagnation of the blood.

Brücke (1857), Lister (1863), Zahn (1875), Cohnheim, and others have, on the contrary, insisted on the importance of the alteration of the endothelial surface.

Baumgarten and Senftleben have tried to prove that in the absence of septic changes coagulation does not take place.

These different views have been more or less discussed by various writers, but we may consider them briefly in the light of our own experiments.

Our six arteries were tied by a skilful operator; the ligatures were perfectly aseptic (with perhaps one exception); the wounds healed without suppuration and by primary intention; yet in all cases well-marked coagulation occurred. We feel, therefore, convinced that the theory of Baumgarten and Senftleben concerning the absence of coagulation when aseptic ligature is used cannot be maintained, and on this point we fully agree with Arnaud.

The shape of the clot, its extension along the side of the artery opposite to that of the collateral branch above the point of occlusion, \&c., all favour the view that stag- 
nation must have at least a share in the causation of thrombosis. A difficulty, however, is raised by the absence as a rule of a coagulum in the distal cul-de-sac, where the blood must be nearly as stagnant as in the proximal cul-de-sac of the artery.

The same difficulty occurs when Brücke's views are considered. The lesion of the intima is practically the same on both sides of the ligature, and yet in our specimens permanent coagulation is the rule on the proximal and the exception on the distal side. Between the two the evidence, so far, is apparently in favour of the old stagnation theory. We believe, however, that both theories are partly correct, but that the endothelial lesions are really started by deficient nutrition due to stagnation. We suspect that the conditions of circulation in the vasa vasorum are not the same above and below the ligature, but it would be premature to discuss this view, as we can adduce no experimental proof in support. It is, however, important to remember that when double ligature is applied to a vessel no coagulation takes place in that vessel between the ligatures for some considerable time. Simple stagnation is therefore not enough. We are thus driven to consider all the theories we have discussed as incomplete. A factor which has not been considered yet may, perhaps, supply the explanation which has yet to be found.

When a fluid containing solid particles circulates in a vessel into which blind appendices open, the conditions of pressure and of distribution of solid particles are not the same in appendices having different directions and openings of various sizes. We only indicate here a differential element, but the discussion of this question would carry us beyond the limits of this paper. ${ }^{1}$

1 That a difference exists between the state of the blood in the proximal and distal culs-de-sac seems to be clearly indicated by the fact that when the vessel is contracted without the inner coats being torn, coagulation (according to Mr. Ballance) is always found on both sides of the ligature. As this is not the case with tight ligature with which rupture of the coats is obtained, it is to be supposed that when loose ligature is used the process of 
Our first conclusion is, therefore, that the occurrence of thrombosis after ligation is not determined (though it may be modified) by septicity ; that it is partly due to stagnation of the blood, and to certain conditions of circulation above the seat of ligature, and secondarily to degenerative changes in the endothelial lining of the vessel.

B. Organisation of the thrombus.-Putting aside the view supported by Weber, Billroth, and others, that the clot may become entirely or in part transformed into some permanent living tissue, there remain two antagonistic theories to consider.

Bubnoff (1867) sought to prove that the organisation of the clot was due to the immigration of leucocytes escaped by diapedesis from the vessels around the artery. Schultz (1877), Senftleben (1879), Ziegler (1889), and others have supported these views by further experiments.

On the other hand, Waldeyer (1867), Cornil and Ranvier, Durante (1872), Riedel (1875), Baumgarten (1876), Shakespeare (1879), Raab (1879), and many others have supported the view that the proliferative changes occurring in the intima were the most important factors in the organisation of the clot.

The facts which we have been able to observe make it impossible for us to agree with Bubnoff and those who think with him. We cannot even accept as satisfactory the conciliatory hypothesis advanced by some, such as Pfitzer and Ziegler, and quite lately Ballance and Edmunds, who seem to imply that both the processes may play an important part in the organisation. We share the views of Cornil and Ranvier and Waldeyer, so well supported by the experiments of Durante, Riedel, Shakespeare, \&c. We, however, take exception to the statement made by Cornil and Ranvier and their followers regarding the region where the proliferation of the intima is most marked. These observers think that the proliferation is most evident in the neighbourhood of the coagulation extends from the proximal to the distal part of the vessel through the constriction. 
ligature. We found, however, that this was the case only (the inner coats being ruptured) when there was little or no thrombosis. ${ }^{1}$ When there was a marked clot, the proliferation of the cells of the intima was most marked at the level of the proximal end of the thrombus, and therefore separated from the ligature by a space equal to the length of the thrombus. Shakespeare has noticed in one of his experiments a marked thickening of the intima at a certain distance from the ligature, but under the influence of Cornil and Ranvier's views he tried to explain this by supposing that he had held the vessel with forceps at that place. We may add here that we have not only observed the part which the tunica intima takes in the organisation of the thrombus, but can furnish by one of our specimens a demonstration of the passivity of the migrated leucocytes. In our second specimen we have shown how the deep parts of the thrombus were invaded by an army of leucocytes coming from the vasa vasorum and periarterial vessels. These leucocytes were most abundant in that part of the clot which showed little if any sign of organisation, and which by comparison with the other specimen was the very part of the thrombus which disappeared by absorption without being permeated by embryonic tissue. Such a fact, bringing into contrast the two processes, shows clearly that the essential factor in the organisation of the thrombus is the proliferation of the cells of the intima in the parts where they can be reached by the blood.

c. The vascularisation of the thrombus has been as great a source of discussion as those questions which we have already dealt with.

Early writers-for instance, Stilling (1834)—described

1 When there is no or little thrombosis, or when there is only an axial fusiform clot, as is often the case when the inner coats are not ruptured, fluid blood can reach the intima as far down as the place of constriction; this, we suppose, is the only explanation of the difference existing in the seat of proliferation of the intima between tight and loose ligature. 
the appearance of vessels in the thrombus without giving any distinct opinion as to their mode of origin. These observations were chiefly based on the study of injected specimens. Stilling noticed that in recent thrombi the periphery was more readily injected, whilst in old thrombi the reverse was the case. From our observations it seems evident that the canals injected by Stilling in recent thrombi were not vessels at all, but simply spaces produced by the shrinking of the fibrin; whilst those injected in older thrombi were the true vessels formed during organisation, vessels which, as we have shown, cannot be efficient, because not channelled, before the end of the second or third week.

Rokitansky (1852) went so far as to say that he had never observed the formation of vessels in a thrombus. Cornil and Ranvier think that the vascularisation of the clot is brought about by the growth of vessels extending from the vasa vasorum into the lumen of the vessel filled by the thrombus. This would take place at the end of the artery where the tunica media has disappeared, and the new vessels would extend within the granulations containing them in a direction parallel to the axis of the vessel, and grow towards the heart.

Hamilton (1881) believes that the extension of the vessels takes place in the form of loops, which penetrate into the clot as they would into a sponge.

Schultz (1877) reverts to the old idea that vascularisation begins within the lumen of the vessels, and evidently admits an independent formation of vessels within the clot, but believes that the organisation depends on the immigrated leucocytes.

Ziegler suggests that at first, at any rate, the vascularisation described by Schultz is not a true vascularisation.

- From what we have already said it will be evident that none of the hypotheses just mentioned cover all the facts which we have observed.

We think we have proved- 
1st. That in a recent thrombus irregular channels are produced by shrinking, and that the blood penetrating into these channels or spaces coagulates after a time. This false vascularisation is the only form of canalisation observed during the first ten days.

2nd. That the proliferating cells of the intima are arranged in the young connective tissue invading the clot in the same way as in other forms of young connective tissue. Branching tracts of spindle-shaped cells are thus formed, and produce the appearance of a vascular network. There is, however, no true circulation through these vessels, most of which have no lumen. This condition may be called potential vascularisation.

3rd. That after a time the inflammatory changes affecting the coats of the vessel lead to the formation of young vessels continuous with the rasa vasorum, and extending through the degenerated middle coat towards the obliterated lumen as well as in other directions, and that ultimately the young periarterial and endoarterial vessels thus formed meet and inosculate. It is only after this inosculation that true circulation becomes possible. Such circulation does not probably take place in a medium-sized artery before the twentieth day. Now it is evident that when it was customary to let the ligature ulcerate through the coats of the vessel there was for a while between the two gaping ends of the artery a tract of young connective tissue. This tract gradually became continuous with the young connective-tissue plug which had replaced the absorbed thrombi. The blood contained in the vessel above and below the point of constriction was therefore separated by a bridge of vascular connective tissue. We have shown that, as the superficial parts of the clot are rapidly organised while the deeper parts of the clot (which the nutrient fluid cannot reach and where organisation is rather deficient) are absorbed, the surface of the plug becomes gradually more and more concave, and sometimes even infundibuliform. Consequently most of the blood-stream is directed towards 
the central portions of the vascular plug, and there is a tendency for the central channels to enlarge. This explains the formation of the central vessels found at various intervals after ligation, which have attracted the attention of Lobstein, Stilling, Blandin, and others. The arborescent sproutings of vessels described by Jones, Ebel, Manec, \&c., do not invalidate this explanation. In fact, Stilling observed that sometimes the central vessel did branch. In all the cases just alluded to the partial re-establishment of circulation had taken place very slowly, for the observations relate to vessels which had already been tied for months or for years. This kind of circulation is, therefore, of little practical interest, since, by the time it becomes evident, the usual collateral circulation is already fully established, and the lesions for which the artery had been tied either cured or beyond the reach of treatment by ligation.

It is perfectly evident that when a tight ligature is used secondary channels may form between the two ends of the constricted vessel. Equally patent is the fact that so long as the ligature and the portion of adventitia which it encloses are not absorbed, the new channels must pass round the ligature. Messrs. Ballance and Edmunds have found that seventy-three days after ligation the ligature was not yet entirely absorbed. It is therefore evident that a direct intermediate central vessel would not be likely to be established before the end of three months when the ligature is applied tightly. As we have seen, this formation of a central vessel is of no moment whatever unless it occurs so rapidly after ligation as to permit the re-establishment of the flow of blood before the desired effects of ligation have taken place. Messrs. Ballance and Edmunds have shown in their experiments that when a ligature is so loosely applied as to cause only slight constriction of the vessel there is no complete obliteration of the lumen of the vessel forty-four, fifty-eight, and even seventy-three days after ligation; in two of their cases a loose clot existed at the seat of constriction, but such a 
clot would be a poor guarantee of obstruction, specially in the case of large vessels and in case of suppuration, as shown by their experiment No. 18. ${ }^{1}$

D. Fate of the ligature.-From our observations it seems evident that after the first irritation caused by the operation has subsided, the tendon ligature remains in the tissues as a non-irritating foreign body. Absorption of the tendon goes on slowly, but long before the process is complete a kind of capsule of vascular young connective tissue surrounds the ligature in every direction, that of the vessel excepted. The ligature, therefore, continues to support and constrict the vessel until it is entirely replaced by connective tissue. The process of solution of the ligature takes place wherever the living tissues come in contact with it, and is more rapid where the ligature is split into fibrils or small bands than where it is smooth and forms dense tracts.

E. Changes observed in the traumatic and irritative periarterial regions. These are interesting, as they show distinctly the relations which proliferative and exudative changes bear to the healing process. It is evident from our experiments that, however perfect the process of healing may be, there is always a slight amount of inflammatory exudation, specially where, owing to the presence of a foreign body (such as a ligature), parts cannot be brought in absolute contact. This exudation has all the anatomical characters ascribed to croupous exudation; it is composed of leucocytes, red bloodcorpuscles, and plasma, from which a network of fibrin soon precipitates. As in the case of other croupous exudations, these products show no tendency towards organisation, but soon degenerate and are absorbed. On the other hand, proliferation of cells takes place actively in the surrounding connective tissue, even the adipose cells showing active signs of proliferative activity. Then the fat is absorbed, the nuclei multiply, giant-cells are formed in the midst of the young sarcomatous-looking 1 'Med.-Chir. Trans.,' vol. lxix (1886), p. 455 . 
tissue, especially round the foreign bodies which are in the wound. In no case has it been possible to find any evidence of the formation of the giant-cells by the coalescence of leucocytes, whilst in many places these cells were found to have the relations of ordinary connectivetissue corpuscles or fat-cells. Gradually, as the exudation is absorbed, this young sarcomatous tissue comes in contact with the ligature, and shows at first embryonic potential vessels, and afterwards pervious or effective ones. The absorption of the periarterial exudation takes place at the same time as that of the clot, or perhaps a little more rapidly, so that the process of organisation goes on at the same time without and within the vessel, and is brought about by proliferation of pre-existing connective-tissue cells.

\section{Clinical.}

Whether it is the best practice to tie an artery, in its continuity, by a tight or a loose ligature, is an old but, as will be recognised, a still debated question. By tight ligature we signify rupture of the inner coats of the vessel, while the loose ligature aims at occlusion by mere compression of the arterial walls. The adoption of the antiseptic system, the possibility of applying an aseptic, absorbable ligature through an aseptic wound, allows us at the present time to survey the whole matter from an entirely new aspect, and the greater part of the existing literature on the subject deals with matters now beside the question, and with conditions which need no longer exist. Even with this state of affairs it is said that loose ligation is the best, the most scientific, and the safest proceeding. To this contention we wholly demur, traversing all the three arguments alleged above in its favour.

Experiments made under the favorable conditions of the physiological laboratory on the perfectly healthy arteries of young animals cannot of course settle such questions, 
considered in their practical or clinical aspects. Still they furnish invaluable information, for they illustrate the typical changes taking place in the normal mode of repair. All the knowledge gained by these experiments has, so to speak, to be translated into the language of practical surgery. Viewed in this light, the results of our experiments furnish, to our minds, strong arguments in favour of tight ligation.

For the sake of convenience, and because the various branches of the subject are clearly and exhaustively set forth, we will adopt generally the headings given by Messrs. Ballance and Edmunds in their paper advocating the advantages of the loose or occluding ligature. The case for ligation without rupture of the internal coats could hardly be better stated than it is in this communication.

It appears to be generally conceded that the properties of a ligature are good when the material is uniform in structure and behaviour; in addition it must be strong, unirritating, easily rendered perfectly aseptic, slowly absorbed, and capable of being tied with a close knot which is not liable to slip. Whether kangaroo tendon, ox aorta, whale tendon, or catgut be used matters comparatively little, especially if the ligature is tied tightly. We may say at once, however, that kangaroo tendon seems to us by far the best of the materials enumerated. In the case of loose ligation the quality of the particular material employed becomes at once a question of importance. A defective catgut ligature, for instance, might be too rapidly absorbed, and this defect would be likely to lead to too rapid return of the blood-stream through a loosely ligatured artery. Such a mischance would matter but little in a laboratory experiment. The artery might return almost to the normal state it was in before ligature, or an interesting diaphragm be formed owing to the perforation of the web of proliferating intima-cells stretching across the lumen of the vessels. But if the artery had been tied for aneurism the chance of cure would have 1 'Med.-Chir. Trans.,' vol. lxix, p. 463. 
been much diminished. It must be remembered that, in practice, when an artery is tied we do not only require to safeguard against secondary hæmorrhage; a distinct object has to be gained, such as the cure of an aneurism or the control of hømorrhage from some more distal vessel which cannot be secured locally. One of us had recently under his care a case in point. A man, aged sixty, had severe hæmorrhage from a cancerous ulceration in the floor of the mouth. Half of the tongue had been removed six months previously. In three attacks the patient lost $90 \mathrm{oz}$. of blood, on one of these occasions losing $60 \mathrm{oz}$. Local remedies proved fruitless. Ligature of the lingual artery was rendered impossible by the presence of extensive cancerous infiltration under the jaw and in the neck. The rather unorthodox treatment was therefore adopted of ligaturing the common carotid. The vessel was far from healthy, and very slight traction on the tendon ligature caused the internal coats to give way distinctly. The wound healed by first intention, and there was no further return of the hæmorrhage.

The more certain a ligature is of occluding the vessel permanently the better is it suited for its purpose. In double distal ligature of the carotid and subclavian for thoracic aneurism the re-establishment of the circulation through the main vessels which had been temporarily obstructed might, even after a long period, vitiate any benefit gained by the operation.

Catgut, being formed of several different tissues twisted together, can never be quite so reliable as a material nor so homogeneous as tendon. The behaviour of catgut when buried in the tissues is also a matter of some uncertainty, and in the case of loose ligation, when it is of extreme importance that the ligature should remain as long as possible in proper contact with the arterial wall, this uncertainty becomes a matter of serious moment. No doubt the defect inherent in catgut is neutralised to a very great extent by chromicising the ligature, but this process renders the material hard 
and less adapted to be tied with a properly close knot. We may mention here that although the experiments described above were made with a chromicised tendon, we now think that this mode of preparation is not really of any advantage, and that by impairing the suppleness of the tendon it interferes with its efficiency. The main point, however, is not so much now the choice of material as the choice of a method of ligation which enables the surgeon to select whatever material he may chance to prefer. A tendon may, of course, be found defective though most carefully selected and prepared. Still, in our opinion, the risk resulting from a defective ligature, or of one that undergoes too rapid absorption, is less if the first knot be tied firmly, whatever the material used. It has been urged, as an argument against tight ligation, that it is not justifiable to do more than is absolutely necessary to attain the end in view. The epithet is too strong in a matter in which there is much to be said on both sides of the question. To our minds it is dangerous to lay down an arbitrary minimum standard inapplicable to all cases. The very expression " rupture" of the coats appears to shock some people, and to imply that the knot of the ligature is drawn not so much with firmness, decision, and a sense of a distinct end to be achieved, as with a species of surgical brutality. The gentleness and quasi-refinement of the one procedure are contrasted with the rough coarseness of the other. But the rupture of the coats will usually occur, whether it is desired or not, whenever these coats are much diseased and stiff and the artery is sufficiently constricted as to cause occlusion. Some margin should be allowed; and the safest practice appears to us to be to do no less than circumstances may possibly demand. Tight ligation allows such a margin, and does so, as we have endeavoured in part already to show, without incurring any extra risk or even disadvantage. We find ourselves unable to subscribe to the opinion that under the antiseptic system it does not matter whether the internal tunics be ruptured or not. We think it is decidedly better to rupture them. Nor will such 
evil consequences follow, with tight ligation, if asepsis fails to be maintained in the wound. The best results will be secured when asepticity is complete, and it is of paramount importance to secure such a condition. Still, failure in this respect may occur. Concerning ourselves now only with the local consequences, we should expect that, in a septic wound, the ligature would be much more rapidly consumed or absorbed. But the occlusion of the vessel will have been secured, as our specimens demonstrate, in the most rapid and efficient manner, and the operation, considered in its mechanical aspects, will have had the best chance of bringing about the results aimed at. Tight ligation, therefore, allows a margin, and one that it is very desirable to provide, for possible failure in the endeavour to secure asepsis.

The restoration of the natural channel through the ligatured portion of the artery, already referred to, must always be a matter of uncertainty. If the knot of a loosely tied ligature gave way almost immediately after ligation the lumen of the vessel might be restored intact. But a considerable time must, under more ordinary circumstances, elapse before a diaphragm is formed, or the occlusion, complete for a while, is tunnelled through. Such restoration will only occur after loose ligation. By some this contingency is considered desirable. We hold the opposite opinion. The assumption that the nutrition of a limb, threatened by the ligation of its main artery, would be saved by the restoration of the temporarily occluded channel, is very theoretical. The limb would die if deprived wholly of blood for, say, twenty-four hours. Any portion of the limb would become gangrenous if similarly starved. The period at which the vitality of a limb is most imperilled is during the first few hours after ligature. Subsequently the efficiency of the collaterals becomes more pronounced. The aneurism, if there be one, diminishes in bulk, and the obstruction is thereby lessened. By the time that the lumen of the ligatured vessel could be safely restored without prejudice to the condition for which ligation was 
performed, the circulation through the limb is already as perfect as it need be. No good can really come of the reopening of the closed channel. It is much more likely in practice that harm might result. The best imaginable condition after ligature of a main artery for aneurism is for the nutrition to be perfectly maintained by means of the collateral circulation. If this physiological result be secured, there is no need to trouble about the absolute restitution of the anatomical condition. The latter, in fact, would only tend to make the return of aneurism more probable.

In the event of suppuration occurring at the seat of ligature, the method of tight ligation still offers, to our minds, the greater security. One of two conditions may occur. Either an abscess may form round the constricted vessel, the ligature still remaining in situ; or, secondly, the loop may cut its way through the vessel, which being thus divided allows the pus to have access between the ends. If the abscess occurs round the vessel, ulceration may take place into it, and lead to fatal hæmorrhage. Specimens abound in museums illustrating this process, one that has been admirably treated of by Syme ${ }^{1}$ and many other writers. Now, the more natural the condition of the artery, the greater is the risk of the hæmorrhage resulting from such ulceration, for the opening is made into a vessel in which the full blood-stream is flowing. The ligatured artery is safer than the sound one. The greater the extent of occlusion and the less the blood-

1 'Contributions to the Path. and Pract. of Surgery,' 1848. On p. 267 Syme writes :- "As this case (q. v.), together with others of hæmorrhage under similar circumstances, has been referred to in support of the opinion that an abscess may be converted into an aneurism by ulceration of a contiguous arterial trunk, I think it right to remark that although arteries frequently open on the surfaces of sinuses and ulcerated cavities, the only instance of communication with an abscess on record is the one supposed to have occurred in University College Hospital." The meaning probably is that, when ulceration into an artery takes place under the circumstances external hæmorrhage is the common result, and an aneurism is unlikely to form. After an opening has formed into the artery the perforation has frequently been found closed by a coagulum. 
current in it, the smaller the risk of grave hæmorrhage. Abscess is not more likely to occur after tight than it is after loose ligation. The occurrence of suppuration is, indeed, a question of septicity, and not of tight or loose ligation. Our specimens show that a good length of vessel-in our opinion more than follows the use of the loose ligature-is absolutely rendered impervious; and it follows, therefore, that the danger from this source after tight ligation is at least no greater than by the other method.

Secondly, it is said the ligature may cut through the adventitia. Experiments and practice appear alike to show that a tightly tied absorbable aseptic ligature does not as a matter of fact cut its way through the vessel, but remains embracing the artery after many days. If the ligature has irritating properties, such as badly prepared catgut may possess, it might work its way through the coats whether it be tied tightly or loosely. The more perfect and more rapid occlusion secured by tight ligature still has the advantage in preventing serious consequences from any such mischance. Or the loop of the ligature may dissolve with undue rapidity, so that the knot with two free ends is set loose. Still the processes set up by the tight ligation render the accident of less consequence than would be the case with loose ligation; for here, again, the more complete and quick closure resulting from the former process offers the best chance of safety under the conditions. Should any of these accidents happen after loose ligation, there is really little save a slightly adherent clot in the vessel to prevent hæmorrhage.

The danger sometimes supposed to result from the tight ligation of arteries in an advanced state of degeneration is, we think, rather theoretical. It must be borne in mind that atheromatous degeneration commences in the deeper parts of the intima, and extends gradually outwards. The altered internal tunics, therefore, would be ruptured with more ease, and in a degenerated vessel might even be divided, when the intention was merely to compress them. 
We believe that security is perfectly maintained if these inner coats are cut through. No doubt it is unnecessary to tie the ligature as tightly on a diseased vessel as on a healthy one in order to effect the rupture. But a very large margin is allowed, for with a flat ligature a degree of force that no operator could practically employ would be necessary to cut through the adventitia even in a very rigid ressel. The giving way of the inner coats will be felt distinctly as the knot is closed, and this unmistakable sensation enables the operator to estimate to a nicety the force required. In tying an artery for aneurism it is best to assume that the vessel is in a diseased state. In practice, as far as our researches and experience extend, no evil results have followed tight ligation of diseased vessels with tendon ligatures, and we believe this to be not only safe, but also the best practice. Flat ligatures offer on the whole the greatest advantages. The knot is closer and more compact than in round ligatures, and the shape enables the band to support the vessel more efficiently. When flat ligatures are used, however, it is of importance to bear in mind that the ligature should be drawn tight slowly, and the second knot should also be closed without any jerk.

We wish it to be clearly understood that we do not dispute the fact that by means of the loose ligature perfect occlusion can be obtained in an artery under suitable conditions. The results obtained by acupressure gave proof that it was possible to occlude an artery by simply approximating the walls by moderate pressure for a short time. But this practice was but short-lived, for it was found to be inconvenient and of uncertain efficiency. It is probable that many of the arteries tied in a large wound, such as that of an amputation, do not have their inner coats ruptured. Again, attempts were made at one time, though not, we believe, in this country, to bring about the permanent occlusion of an artery in its continuity by means of gently pressing together the walls, a special form of arterial clamp being used for the purpose. This practice, however, 
MEDIUM-SIZED ARTERIES AND IN TENDON LIGATURES. 433

was soon abandoned. Loose ligature is decidedly preferable to any such method. Our contention is that the firm ligature also occludes perfectly, while it is applicable to more-in fact, to all cases; further, it is the safest method when the healthiness of the ligatured vessel is a matter of doubt.

\section{Genneral Conclusions.}

I. We advocate the practice of tight as preferable to that of loose ligation, at least as far as general application is concerned,-1. Because it ensures more complete and permanent obliteration of the vessel. 2. It brings about tive desired condition with more rapidity. 3. It prevents possible re-establishment of circulation through the vessel. 4. It gives more uniform results. 5. It requires less skill. Any error in the direction of tying the artery with more force than is actually required will lead to no bad consequences. 6. It allows a margin for any possible complications that may arise.

II. The use of an aseptic tendon ligature is recommended -1. Because such ligatures are very uniform in structure and composition. 2. Because being flat they are less likely to injure the external coat of the vessel than a small round ligature, and for the same reason the knot is more compact though not smaller. 3. Because although tendon remains unabsorbed for a great length of time it causes no irritation.

1 The method was known in Germany as "Arterienklausur." See Billroth's 'Clinical Surgery,' New Sydenham Society's Translation, p. 458. 


\section{APPENDIX.}

\section{Bibliography.}

This bibliography does not pretend to be complete, but gives the sources of statements or views which have been alluded to in the discussion.

\begin{tabular}{|c|c|c|c|c|}
\hline No. & Authors. & Date. & References. & Title or nature of contribution. \\
\hline 1 & Arnaud & 1880 & $\begin{array}{l}\text { Contributions à l'étude de } \\
\text { la ligature dans le traite- } \\
\text { ment des anévrismes }\end{array}$ & $\begin{array}{l}\text { Coagulation occurs in } \\
\text { vessels tied with carbo- } \\
\text { lised catgut ligature. }\end{array}$ \\
\hline 2 & Auerbach & 1877 & Dissert. (Bonn) & $\begin{array}{l}\text { Ueber d. Obliterat. d. Ar- } \\
\text { terien nach Ligatur. }\end{array}$ \\
\hline $\mathbf{3}$ & $\begin{array}{l}\text { Ballance } \\
\text { (C. A.), } \\
\text { Edmunds } \\
\text { (W.) }\end{array}$ & 1886 & $\begin{array}{l}\text { Medico-Chirurg. Transac- } \\
\text { tions, 2nd series, li }\end{array}$ & $\begin{array}{l}\text { The Ligature of the larger } \\
\text { Arteries in their con- } \\
\text { tinuity: an Experimental } \\
\text { Inquiry. } \\
\text { 1. It is neither necessary } \\
\text { nor advisable to rupture } \\
\text { the coats of the vessels. } \\
\text { 2. The lumen of the vessel } \\
\text { must be completely or } \\
\text { almost completely oblite- } \\
\text { rated, and the integrity } \\
\text { of the walls must be re- } \\
\text { spected. } \\
\text { 3. The round ligature, of } \\
\text { small size and possessed } \\
\text { of certain qualities, is } \\
\text { the best (small, round, } \\
\text { absorbable ligature). } \\
\text { - }\end{array}$ \\
\hline 5 & Baumgarten & 1876 & $\begin{array}{l}\text { Centralbl. f. d. med. Wis- } \\
\text { sensch., No. xxxiv, Aug. } \\
19\end{array}$ & $\begin{array}{l}\text { Organisation of thrombus } \\
\text { entirely due to changes } \\
\text { in intima. Thrombus } \\
\text { passive. }\end{array}$ \\
\hline & $"$ & 1877 & $\begin{array}{c}\text { Die sögen. Organisation } \\
\text { d. Thrombus, Leipzig }\end{array}$ & $\begin{array}{l}\text { Organisation of clot in } \\
\text { doubly ligatured arteries } \\
\text { in a rabbit. }\end{array}$ \\
\hline & " & 1886 & $\begin{array}{l}\text { Berl. klin. Wochenschr., } \\
\text { xxiii, p. } 385\end{array}$ & - \\
\hline
\end{tabular}


MEDIOM-SIZED ABTERIES AND IN TENDON LIGATURES. 435

\begin{tabular}{|c|c|c|c|c|}
\hline No. & Authors. & Date. & References. & Title or nature of contribution. \\
\hline 6 & Billroth & 1856 & $\begin{array}{l}\text { Lectures on Surgical Pa- } \\
\text { thology and Therapeu- } \\
\text { tics, 8th edit., translated } \\
\text { by Hackley, New Syden- } \\
\text { ham Society }\end{array}$ & $\begin{array}{l}\text { Presence of clot in proxi- } \\
\text { mal and distal end of } \\
\text { large arteries tied in } \\
\text { their continuity inclines } \\
\text { to believe that leuco- } \\
\text { cytes contained in the } \\
\text { clot play an important } \\
\text { part in organisation. } \\
\text { Views not very clear. }\end{array}$ \\
\hline 7 & Blandin & 1840 & Journal Hebdomadaire, & $\begin{array}{l}\text { Axial vessel formed after } \\
\text { ligature }\end{array}$ \\
\hline 8 & Brücke & 1857 & $\begin{array}{l}\text { Arch. für Path. Anat., } \\
\text { No. 13, xii; Brit. and } \\
\text { Foreign Med.-Chir. Rev. }\end{array}$ & $\begin{array}{l}\text { Stagnation not sufficient } \\
\text { cause of coagulation. }\end{array}$ \\
\hline 9 & Bubnoff & 1867 & Centralblatt, No. 48 & $\begin{array}{l}\text { Organisation of thrombus } \\
\text { due to immigration of } \\
\text { leucocytes (doubly tied } \\
\text { veins). Vermilion spread } \\
\text { in wound found within } \\
\text { vessel in leucocytes. }\end{array}$ \\
\hline 10 & Burdach & 1885 & $\begin{array}{l}\text { Arch. für Path. Anat., c, } \\
\text { p. } 217\end{array}$ & $\begin{array}{l}\text { Ueber d. Senftlebenschen } \\
\text { Versuch., \&c. Carotid } \\
\text { artery of dead men and } \\
\text { rabbits introduced into } \\
\text { the abdomen of another } \\
\text { animal became filled up } \\
\text { with vascular connective } \\
\text { tissue, which penetrated } \\
\text { into the vessel at the in- } \\
\text { jured ends. }\end{array}$ \\
\hline 12 & $\begin{array}{l}\text { Callender } \\
\text { Cohnheim }\end{array}$ & $\begin{array}{l}1878 \\
1880\end{array} \mid$ & $\begin{array}{l}\text { Clinical Transactions, ix, } \\
\text { p. } 103 \text {. } \\
\text { Vorles. über allgem. } \mathrm{Pa} \text { - } \\
\text { thologie }\end{array}$ & $\begin{array}{l}\text { Proposal of kangaroo ten- } \\
\text { don ligature. }\end{array}$ \\
\hline 13 & $\begin{array}{c}\text { Cornil and } \\
\text { Ranvier } \\
\quad "\end{array}$ & $\left|\begin{array}{l}1868 \\
1881\end{array}\right|$ & $\mid \begin{array}{cc}\text { Archives de } & \text { Physiologie, } \\
\text { t. i } & \\
\text { Manuel } & \text { d'Histologie } \\
\text { Pathologique, 2nd edit., } \\
\text { vol. i, p. 598 }\end{array}$ & $\begin{array}{l}\text { Contributions à l'histo- } \\
\text { logie normale et patho- } \\
\text { logique de la tunique in- } \\
\text { terne des artéres et de } \\
\text { l'endocarde. Vasculari- } \\
\text { sation by extension of } \\
\text { vasa vasorum into the } \\
\text { thrombus. Organisation } \\
\text { of thrombus due to neo- } \\
\text { formation beginning in } \\
\text { walls of vessels. Bub- } \\
\text { noff's experiment does } \\
\text { not succeed with simple } \\
\text { ligature. }\end{array}$ \\
\hline
\end{tabular}




\begin{tabular}{|c|c|c|c|c|}
\hline No. & Authors. & ate. & References. & Title or nature of contribation \\
\hline 14 & Delépine & 1887 & Brit. Med. Journal, ii & $\begin{array}{l}\text { Organisation of thrombus } \\
\text { formed in an artery after } \\
\text { ligature. }\end{array}$ \\
\hline 15 & Dent & 1881 & $\begin{array}{l}\text { Medico-Chirurg. Transac- } \\
\text { tions, lxiv, March }\end{array}$ & $\begin{array}{l}\text { A case of innominate } \\
\text { aneurism, \&c., with re- } \\
\text { marks on the behaviour } \\
\text { of a tendon ligature. }\end{array}$ \\
\hline 16 & Durante & 1872 & $\begin{array}{l}\text { Archives de Physiologie, } \\
\text { p. } 491\end{array}$ & $\begin{array}{l}\text { Sur l'organisation du } \\
\text { caillot dans les vaisseaux. }\end{array}$ \\
\hline & " & 1872 & $\begin{array}{l}\text { Wiener med. Jahrb., iii, } \\
\text { iv, pp. 143-160 }\end{array}$ & $\begin{array}{l}\text { Fallacy of Bubnoff's ex- } \\
\text { periment, in which ne- } \\
\text { crosis of walls of blood- } \\
\text { vessels is brought about, } \\
\text { unlike what occurs in } \\
\text { ordinary ligature. }\end{array}$ \\
\hline 17 & Ebel (von) & 1826 & $\begin{array}{l}\text { De Naturâ Medicatrici } \\
\text { sicubi Arteriæ vulneratæ } \\
\text { et ligatæ fuerint (Gies- } \\
\text { sen) }\end{array}$ & $\begin{array}{l}\text { Vessels sprouting from } \\
\text { end of tied arteries. }\end{array}$ \\
\hline 18 & Fod & - & $\begin{array}{l}\text { Arch. per le Science Méd., } \\
\text { iii, No. iv }\end{array}$ & $\begin{array}{l}\text { Elements of repair derived } \\
\text { from intima, and granu- } \\
\text { lation tissue passing } \\
\text { through the walls. }\end{array}$ \\
\hline 19 & Froriep & - & $\begin{array}{l}\text { Billroth, Lectures, \&c., } \\
\text { fig. 30, i, p. } 157\end{array}$ & $\begin{array}{l}\text { Organisation of thrombus } \\
\text { after ligature (drawing). } \\
\text { Clot on distal and proxi- } \\
\text { mal ends. }\end{array}$ \\
\hline 20 & & 1830 & $\begin{array}{l}\text { Diseases and Injuries of } \\
\text { Arteries }\end{array}$ & - \\
\hline 21 & $\begin{array}{c}\text { Hamilton } \\
,\end{array}$ & $\begin{array}{l}1881 \\
1889\end{array}$ & $\begin{array}{l}\text { Edinb. Medical Journal, } \\
\text { xxvii, p. 400. } \\
\text { Text-book of Pathology, } \\
\text { pp. 302, 307 }\end{array}$ & $\begin{array}{l}\text { Organisation of thrombus } \\
\text { in ligatured artery chiefly } \\
\text { due to penetration of } \\
\text { vessels derived from vasa } \\
\text { vasorum, pushing before } \\
\text { them young connective- } \\
\text { tissue corpuscles, which } \\
\text { ultimately organise into } \\
\text { fibrous tissue which re- } \\
\text { places the thrombus, the } \\
\text { clot acting simply as a } \\
\text { support; a kind of sponge }\end{array}$ \\
\hline 22 & Hasse & 1846 & $\begin{array}{l}\text { The Diseases of the Organs } \\
\text { of Circulation and Re- } \\
\text { spiration }\end{array}$ & \\
\hline 23 & & 1815 & $\begin{array}{l}\text { Diseases and Injuries of } \\
\text { Arteries }\end{array}$ & - \\
\hline 24 & Holmes (T.) & 1884 & $\begin{array}{l}\text { System of Surgery } \\
\text { British Medical Associa- } \\
\text { tion, Aug., } 1890\end{array}$ & $\begin{array}{l}\text { Has always been an advo- } \\
\text { cate of tight ligature on } \\
\text { practical grounds. }\end{array}$ \\
\hline
\end{tabular}


MEDIOM-SIZED ARTERIES AND IN TENDON LIGATURES. 437

\begin{tabular}{|c|c|c|c|c|}
\hline No. & Authors. & Date. & References. & Title or nature of contribution. \\
\hline 25 & Hunter(John) & 1785 & \begin{tabular}{|cc} 
Traité du Sang et des \\
Inflammations \\
(Trachelot), t. iii
\end{tabular} & $\begin{array}{l}\text { Vascularisation of clot be- } \\
\text { ginning within the tissues } \\
\text { of the vessel, as shown } \\
\text { by injections. The ques- } \\
\text { tion of organisation of the } \\
\text { clot began to be brought } \\
\text { forward by J. Hunter. }\end{array}$ \\
\hline 26 & $\begin{array}{l}\text { Jones } \\
\text { (J. F. D.) }\end{array}$ & 1805 & $\begin{array}{l}\text { A Treatise on the Pro- } \\
\text { cess employed by Nature } \\
\text { in suppressing Hæmor- } \\
\text { rhages, \&c. }\end{array}$ & $\begin{array}{l}\text { Inflammatory changes fol- } \\
\text { lowing ligation. }\end{array}$ \\
\hline 27 & Lee & 1870 & $\begin{array}{l}\text { Lectures on Subjects con- } \\
\text { nected with Practical } \\
\text { Pathology and Surgery, i }\end{array}$ & - \\
\hline 28 & Lister & 1881 & $\begin{array}{l}\text { The Lancet, i, pp. } 201 \\
\text { and } 275\end{array}$ & $\begin{array}{l}\text { On chromic catgut liga- } \\
\text { ture; fibrous ring taking } \\
\text { place of the ligature. }\end{array}$ \\
\hline & " & 1883 & Lancet & $\begin{array}{l}\text { Stagnation not sufficient } \\
\text { to account for throm- } \\
\text { bosis. }\end{array}$ \\
\hline 29 & Lobstein & - & Anat. Path., vol. i, p. 298 & $\begin{array}{l}\text { Axial vessel formed after } \\
\text { ligature. }\end{array}$ \\
\hline 30 & $\begin{array}{c}\text { MacEwen } \\
\text { " }\end{array}$ & $\begin{array}{l}1878 \\
1879\end{array}$ & $\begin{array}{l}\text { British Medical Journal, } \\
\text { ii, p. 359 } \\
\text { Id., i, p. } 272\end{array}$ & $\begin{array}{l}\text { Chromic catgut ligature } \\
\text { proposed. } \\
\text { Young vessels sprouting } \\
\text { from end of ligatured } \\
\text { artery. }\end{array}$ \\
\hline 31 & Manec & - & $\begin{array}{l}\text { Traité de la Ligature des } \\
\text { Artères }\end{array}$ & - \\
\hline 32 & Moore & 1870 & $\begin{array}{l}\text { Holmes' Syst. of Surgery, } \\
\text { i, p. } 712\end{array}$ & 一 \\
\hline 33 & Paget & 1870 & $\begin{array}{l}\text { Lectures on Surgical Pa- } \\
\text { thology, 3rd edit., pp. } \\
160-208\end{array}$ & $\begin{array}{l}\text { References to Hunter, } \\
\text { Stilling, and Billroth. }\end{array}$ \\
\hline 34 & Pfitzer & - & $\begin{array}{l}\text { Arch. f. Path. Anat., } \\
\text { lexvii, p. } \mathbf{3 9 7}\end{array}$ & $\begin{array}{l}\text { Elements of repair derived } \\
\text { both from the endothe- } \\
\text { lium and granulation } \\
\text { tissue passing through } \\
\text { the walls of the vessel. }\end{array}$ \\
\hline 35 & Pitres & 1875 & Archives de Physiologie & $\begin{array}{l}\text { Recherches expérimen- } \\
\text { tales sur le mode de for- } \\
\text { mation des caillots. }\end{array}$ \\
\hline 36 & Porta (L.) & 1845 & $\begin{array}{l}\text { Delle alterazioni patolo- } \\
\text { giche delle Arterie per } \\
\text { la legatura e la torsione } \\
\text { (Milano) }\end{array}$ & \\
\hline \multirow[t]{2}{*}{37} & \multirow{2}{*}{ Quincke } & 1876 & $\begin{array}{l}\text { Ziemssen's Cyclopæedia of } \\
\text { Practice of Medicine, } \\
\text { vol. vi, p. } \mathbf{3 6 3}\end{array}$ & \multirow{2}{*}{$\begin{array}{l}\text { Diseases of the Arteries. } \\
\text { Reference to the views of } \\
\text { Durante, Thiersch, Wal- } \\
\text { deyer, \&c. Quincke does } \\
\text { sions can take place be- } \\
\text { an artery so long as the }\end{array}$} \\
\hline & & & $\begin{array}{l}\text { that ad } \\
\text { osite walls } \\
\text { sts. }\end{array}$ & \\
\hline
\end{tabular}




\begin{tabular}{|c|c|c|c|c|}
\hline No. & Anthors. & Daves & References & Titse or nature of contribution. \\
\hline 38 & $\begin{array}{l}\text { Reckling. } \\
\text { hausen }\end{array}$ & $|\overline{1879}|$ & $\begin{array}{l}\text { Langenbeck's Arch. f } \\
\text { klin. Chir., xxiii, p. } 156 \\
\text { Virch. Archiv, lxxv } \\
\text { Centralbl. f. d. med. } \\
\text { Wissensch., May 31st } \\
\text { - }\end{array}$ & $\begin{array}{l}\text { Ueber die Fntwickelung } \\
\text { der Narbe im Blutgefäss } \\
\text { nach Unterbindung (full } \\
\text { references). } \\
\text { Exclusive part taken by } \\
\text { endothelium in organisa- } \\
\text { tion of thrombus. } \\
\text { Thrombus takes no part } \\
\text { in organisation. Organ- } \\
\text { isation of thrombus } \\
\text { through leucocytes. }\end{array}$ \\
\hline 40 & Richardson & 1858 & $\begin{array}{l}\text { Cause of the Coagulation } \\
\text { of the Blood }\end{array}$ & Stagnation not sufficient. \\
\hline 411 & Riedel & 875 & $\begin{array}{l}\text { Dentsch. Zeitschr. f. Chir., } \\
\text { vi }\end{array}$ & $\begin{array}{l}\text { Organisation of thrombus } \\
\text { due to proliferation of en- } \\
\text { dothelium. Adhesion of } \\
\text { two endothelial surfaces } \\
\text { may take place without } \\
\text { intervention of a clot. }\end{array}$ \\
\hline 42 & Rindfleisch & $\mid 1872$ & $\begin{array}{l}\text { A Manual of Pathological } \\
\text { Histology, translated by } \\
\text { Buchanan Baxter, i }\end{array}$ & $\begin{array}{l}\text { Organisation of thrombus } \\
\text { due to immigration of } \\
\text { leucocytes. Absorption } \\
\text { and softening of clot } \\
\text { discussed. }\end{array}$ \\
\hline & " & 1888 & $\begin{array}{l}\text { Traite d'Histologie Patho- } \\
\text { logique, traduit sur la } \\
\text { 6me 6dit., allemande par } \\
\text { F. Gross et J. Schmitt, } \\
\text { p. } 69\end{array}$ & Id. \\
\hline 43 & Rokitansky & 1852 & $\begin{array}{l}\text { A Manual of Pathological } \\
\text { Anatomy, iv, p. } \mathbf{3 2 7}\end{array}$ & $\begin{array}{l}\text { Does not believe in vas- } \\
\text { cularisation of the throm- } \\
\text { bus. }\end{array}$ \\
\hline 44 & & & Deutsch. Zeitschr. f. Chir., & $\begin{array}{l}\text { Thrombus takes no part } \\
\text { in organisation. }\end{array}$ \\
\hline & " & |1878 & $\begin{array}{l}\text { Centralbl. f. d. med. Wis- } \\
\text { sensch., ix, March } 2\end{array}$ & $\begin{array}{l}\text { Leucocytes fed with cin- } \\
\text { nabar pass into the lu- } \\
\text { men of a vessel singly } \\
\text { or doubly ligatured ; in- } \\
\text { tima takes no part. The } \\
\text { clot is canalised from the } \\
\text { lumen of the occluded } \\
\text { vessel. }\end{array}$ \\
\hline 45 & $\begin{array}{l}\text { Senftleben } \\
\text { (Cohnheim) }\end{array}$ & 1879 & $\begin{array}{l}\text { Virchow's Archiv, lxxvii, } \\
\text { p. } 421\end{array}$ & $\begin{array}{l}\text { Senftleben experiment:- } \\
\text { A large artery (aorta) } \\
\text { of a rabbit doubly tied; } \\
\text { the part thus cut off } \\
\text { allowed to remain for } \\
\text { three days, and then in- } \\
\text { serted into the peritoneal } \\
\text { cavity of another rabbit, } \\
\text { where the clot organises } \\
\text { as in ordinary vessels. }\end{array}$ \\
\hline
\end{tabular}


MEDIUY-SIZED ARTERIES AND IN THNDON LIGATURES. 439

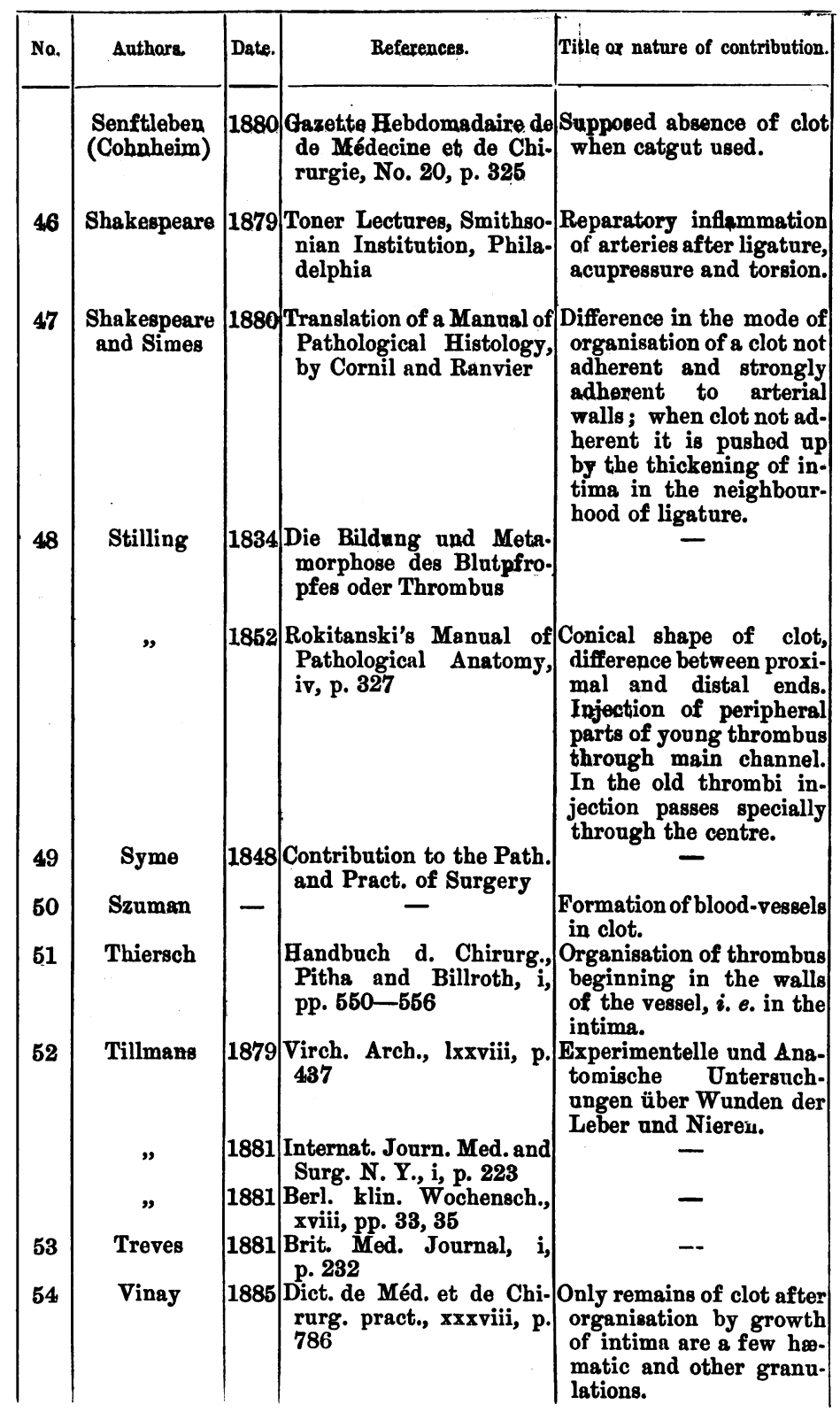


CHANGES OBgERVED IN HEALTHY ARTERIES, ETC.

\begin{tabular}{|c|c|c|c|c|}
\hline No. & Authors. & Date. & References. & Title or nature of contribution. \\
\hline 55 & Virchow & 1856 & $\begin{array}{l}\text { Gesammelte Abhand- } \\
\text { lungen, Handb. d. Spec. } \\
\text { Path. }\end{array}$ & $\begin{array}{l}\text { Papers on blood coagula- } \\
\text { tion, thrombosis, and } \\
\text { embolism. Stagnation } \\
\text { cause of thrombosis; } \\
\text { great importance of clot } \\
\text { in organisation. }\end{array}$ \\
\hline 56 & Waldeyer & 1867 & $\begin{array}{l}\text { Arch. für Path. Anat., xl, } \\
\text { pp. 379-391 }\end{array}$ & $\begin{array}{l}\text { Zur pathol. Anatomie der } \\
\text { Wundkrankh. Intima } \\
\text { most important element } \\
\text { in repair. }\end{array}$ \\
\hline 57 & Warren & 1886 & $\begin{array}{l}\text { Healing of Arteries after } \\
\text { Ligature }\end{array}$ & \\
\hline 58 & Weber & 1865 & $\begin{array}{l}\text { Handbuch der Allge- } \\
\text { meinen und Speciallen } \\
\text { Chirurgie, von Pitha und } \\
\text { Billroth, Bd. i, Lief. 1, } \\
\text { p. } 143\end{array}$ & $\begin{array}{l}\text { Supposes that clot con- } \\
\text { tains in itself the ele- } \\
\text { ments of organisation. } \\
\text { Anastomosis of vessels } \\
\text { formed in the clot with } \\
\text { those of the tunica ad- } \\
\text { ventitia. Good diagram } \\
\text { showing double origin of } \\
\text { vessels of thrombus. }\end{array}$ \\
\hline 59 & Zahn & 1875 & Virchow's Archiv, lxxii & Unters. über Thrombose. \\
\hline 60 & Ziegler & 1884 & $\begin{array}{|cc|}\text { Pathological } & \text { Anatomy, } \\
\text { translated by Donald } \\
\text { MacAlister, ii, p. } 9\end{array}$ & $\begin{array}{l}\text { Organisation of thrombus, } \\
\text { discussion of views. Ex. } \\
\text { travasated leucocytes } \\
\text { have the chief share in } \\
\text { the formative process; } \\
\text { the active participation } \\
\text { of endothelial cells is not } \\
\text { excluded. Good diagram } \\
\text { of organisation of throm. } \\
\text { bus after alteration of } \\
\text { constricted portion. }\end{array}$ \\
\hline
\end{tabular}

(For report of the discussion on this paper, see ' Proceedings of the Royal Medical and Chirurgical Society,' Third Series, vol. iii, p. 153.) 